\title{
Retrieval of ozone column content from airborne Sun photometer measurements during SOLVE II: comparison with coincident satellite and aircraft measurements
}

\author{
J. M. Livingston ${ }^{1}$, B. Schmid ${ }^{2}$, P. B. Russell ${ }^{3}$, J. A. Eilers ${ }^{3}$, R. W. Kolyer ${ }^{3}$, J. Redemann ${ }^{2}$, S. A. Ramirez ${ }^{2}$, J.-H. Yee ${ }^{4}$, \\ W. H. Swartz ${ }^{4}$, C. R. Trepte $^{5}$, L. W. Thomason ${ }^{5}$, M. C. Pitts ${ }^{5}$, M. A. Avery ${ }^{5}$, C. E. Randall ${ }^{6}$, J. D. Lumpe ${ }^{7}$, \\ R. M. Bevilacqua ${ }^{8}$, M. Bittner ${ }^{9}$, T. Erbertseder ${ }^{9}$, R. D. McPeters ${ }^{10}$, R. E. Shetter ${ }^{11}$, E. V. Browell ${ }^{5}$, J. B. Kerr ${ }^{12}$, and \\ K. Lamb $\mathbf{L a}^{13}$ \\ ${ }^{1}$ SRI International, Menlo Park, CA, USA \\ ${ }^{2}$ Bay Area Environmental Research Institute, Sonoma, CA, USA \\ ${ }^{3}$ NASA Ames Research Center, Moffett Field, CA, USA \\ ${ }^{4}$ Applied Physics Laboratory, Johns Hopkins University, Laurel, MD, USA \\ ${ }^{5}$ NASA Langley Research Center, Hampton, VA, USA \\ ${ }^{6}$ Laboratory for Atmospheric and Space Physics, University of Colorado, Boulder, CO, USA \\ ${ }^{7}$ Computational Physics, Inc., Springfield, VA, USA \\ ${ }^{8}$ Naval Research Laboratory, Washington D.C., USA \\ ${ }^{9}$ DLR (German Aerospace Center), Oberpfaffenhofen, Wessling, Germany \\ ${ }^{10}$ NASA Goddard Space Flight Center, Greenbelt, MD, USA \\ ${ }^{11}$ National Center for Atmospheric Research, Boulder, CO, USA \\ ${ }^{12}$ Environment Canada, Cobble Hill, BC, Canada \\ ${ }^{13}$ International Ozone Services, Inc., Toronto, ON, Canada
}

Received: 22 October 2004 - Published in Atmos. Chem. Phys. Discuss.: 14 January 2005

Revised: 15 June 2005 - Accepted: 8 July 2005 - Published: 8 August 2005

\begin{abstract}
During the 2003 SAGE (Stratospheric Aerosol and Gas Experiment) III Ozone Loss and Validation Experiment (SOLVE) II, the fourteen-channel NASA Ames Airborne Tracking Sunphotometer (AATS-14) was mounted on the NASA DC-8 aircraft and measured spectra of total and aerosol optical depth (TOD and AOD) during the sunlit portions of eight science flights. Values of ozone column content above the aircraft have been derived from the AATS14 measurements by using a linear least squares method that exploits the differential ozone absorption in the seven AATS-14 channels located within the Chappuis band. We compare AATS-14 columnar ozone retrievals with temporally and spatially near-coincident measurements acquired by the SAGE III and the Polar Ozone and Aerosol Measurement (POAM) III satellite sensors during four solar occultation events observed by each satellite. RMS differences are $19 \mathrm{DU}$ (7\% of the AATS value) for AATS-SAGE and $10 \mathrm{DU}$ (3\% of the AATS value) for AATS-POAM. In these checks of consistency between AATS-14 and SAGE III or POAM III
\end{abstract}

Correspondence to: J. M. Livingston

(jlivingston@mail.arc.nasa.gov) ozone results, the AATS-14 analyses use airmass factors derived from the relative vertical profiles of ozone and aerosol extinction obtained by SAGE III or POAM III.

We also compare AATS-14 ozone retrievals for measurements obtained during three DC- 8 flights that included extended horizontal transects with total column ozone data acquired by the Total Ozone Mapping Spectrometer (TOMS) and the Global Ozone Monitoring Experiment (GOME) satellite sensors. To enable these comparisons, the amount of ozone in the column below the aircraft is estimated either by assuming a climatological model or by combining SAGE and/or POAM data with high resolution in-situ ozone measurements acquired by the NASA Langley Research Center chemiluminescent ozone sensor, FASTOZ, during the aircraft vertical profile at the start or end of each flight. Resultant total column ozone values agree with corresponding TOMS and GOME measurements to within 10-15 DU $(\sim 3 \%)$ for AATS data acquired during two flights - a longitudinal transect from Sweden to Greenland on 21 January, and a latitudinal transect from $47^{\circ} \mathrm{N}$ to $35^{\circ} \mathrm{N}$ on 6 February. For the round trip DC- 8 latitudinal transect between

(C) 2005 Author(s). This work is licensed under a Creative Commons License. 
$34^{\circ} \mathrm{N}$ and $22^{\circ} \mathrm{N}$ on 19-20 December 2002, resultant AATS14 ozone retrievals plus below-aircraft ozone estimates yield a latitudinal gradient that is similar in shape to that observed by TOMS and GOME, but resultant AATS values exceed the corresponding satellite values by up to $30 \mathrm{DU}$ at certain latitudes. These differences are unexplained, but they are attributed to spatial and temporal variability that was associated with the dynamics near the subtropical jet but was unresolved by the satellite sensors.

For selected cases, we also compare AATS-14 ozone retrievals with values derived from coincident measurements by the other two DC- 8 based solar occultation instruments: the National Center for Atmospheric Research Direct beam Irradiance Airborne Spectrometer (DIAS) and the NASA Langley Research Center Gas and Aerosol Monitoring System (GAMS). AATS and DIAS retrievals agree to within RMS differences of $1 \%$ of the AATS values for the 21 January and 19-20 December flights, and $2.3 \%$ for the 6 February flight. Corresponding AATS-GAMS RMS differences are $\sim 1.5 \%$ for the 21 January flight; GAMS data were not compared for the 6 February flight and were not available for the 19-20 December flight. Line of sight ozone retrievals from coincident measurements obtained by the three DC- 8 solar occultation instruments during the SAGE III solar occultation event on 24 January yield RMS differences of $2.1 \%$ for AATS-DIAS and $0.5 \%$ for AATS-GAMS.

\section{Introduction}

The second SAGE III Ozone Loss and Validation Experiment (SOLVE II) was an international measurement campaign conducted during Arctic winter 2003 to acquire correlative data for validation of Stratospheric Aerosol and Gas Experiment (SAGE) III measurements, and to study polar winter ozone loss rates and related photochemical processes, polar stratospheric clouds, and polar winter transport and dynamics processes. During SOLVE II, the NASA DC-8 research aircraft deployed from NASA Dryden Flight Research Center (DFRC) at Edwards Air Force Base (AFB), California to Kiruna, Sweden on 9 January and flew 12 science missions out of Kiruna before its return to DFRC on 6 February. The DC-8 instrument payload consisted of a variety of in-situ and active and passive remote sensors, including three solar occultation instruments: the fourteen-channel NASA Ames Airborne Tracking Sun photometer (AATS14), the NASA Langley Gas and Aerosol Monitoring System (GAMS)-Langley Airborne A-Band Spectrometer (LAABS) (Pitts et al., 2005 ${ }^{1}$ ) and the National Center for Atmospheric

\footnotetext{
${ }^{1}$ Pitts, M. C., Thomason, L. W., Zawodny, J. M., Wenny, B. N., Livingston, J. M., Russell, P. B., Yee, J.-H., Swartz, W. H., and Shetter, R. E.: Ozone observations by the Gas and Aerosol Measurement Sensor during SOLVE II, Atmos. Chem. Phys., in preparation, 2005.
}

Research (NCAR) Direct beam Irradiance Airborne Spectrometer (DIAS) (Swartz et al., 2005; Shetter and Muller, 1999).

AATS-14 obtained measurements during the sunlit segments of 12 science flights, including two flights based out of DFRC prior to the deployment to Kiruna and the return transit flight from Kiruna to DFRC. In this paper, data from eight of these flights have been analyzed in detail to yield spectra of total and aerosol optical depth (TOD and AOD), and to retrieve values of ozone column content above the DC-8 flight altitude. In a companion SOLVE II paper (Russell et al., 2005), AATS-14 slant transmission and AOD retrievals are compared with analogous SAGE III, POAM III, and DIAS measurements. In this paper, we compare AATS14 ozone retrieval results with coincident or near-coincident measurements obtained with the SAGE III, POAM (Polar Ozone and Aerosol Measurement) III, TOMS (Total Ozone Mapping Spectrometer), and GOME (Global Ozone Monitoring Experiment) satellite sensors, and with the DC- 8 based GAMS and DIAS instruments. To our knowledge, this is the first published report of a sub-orbital airborne Sun photometer having been used to retrieve columnar ozone.

\section{AATS-14 instrument description}

The NASA Ames Airborne Tracking Sunphotometer (AATS14) measures the direct beam solar transmission in 14 spectral channels from 354 to $2138 \mathrm{~nm}$. AATS-14 azimuth and elevation motors, controlled by tracking-error signals derived from a quad-cell photodiode, rotate a tracking head to lock on to the solar beam and maintain detectors normal to it. During SOLVE II, the instrument was mounted on the NASA DC- 8 in a custom manufactured fairing located on top of the aircraft just in front of the wing and slightly left of the aircraft centerline. This allowed the AATS-14 tracking head to be positioned outside and above the skin of the aircraft, which afforded an unobstructed view of the sun for all solar azimuth angles between $180^{\circ}$ and $360^{\circ}$ (i.e., to the left) relative to the aircraft heading for all solar zenith angles. For relative solar azimuth angles between $0^{\circ}$ and $180^{\circ}$ (i.e., to the right relative to aircraft heading), the view was unobstructed for all solar zenith angles $<65^{\circ}$, but for solar zenith angles $>65^{\circ}$ it was partially obstructed by the aircraft tail, a VHF antenna, or a satellite communications antenna enclosure for certain azimuth angles. Because the other two solar occultation instruments on the DC- 8 were located in the cabin and viewed out optical ports on the left side of the aircraft, all SOLVE II DC-8 flights were designed to include sun runs with the sun positioned to the left of the aircraft heading. AATS-14 was the only sun-tracking sensor that was able to acquire any data when the sun was located to the right of the aircraft heading, and useful science data have been derived from AATS-14 measurements obtained under such conditions. However, we have judiciously screened these data 
because analysis revealed that for certain angles these measurements were contaminated by diffuse light due to what is thought to have been reflection of the incoming solar beam off the aircraft fuselage or attached structures.

Each science channel in AATS-14 consists of a baffled entrance path, interference filter, photodiode detector, and integral preamplifier. The filter/detector/preamp sets are temperature controlled to avoid thermally induced calibration changes. The module that contains the science channels and the tracking photodiode is protected from the outside air by a quartz window that is exposed to the ambient air stream. In an effort to prevent window fogging or frost a foil heater is mounted on the inside surface of this window. The heater foil has a hole for each science channel and for the tracking detector, to permit the solar beam to pass through.

Despite the foil heater, during the first three science flights (12, 14, 16 January) out of Kiruna thin patches of frost formed on the internal surface of the quartz window and caused a decrease in the measured transmission of the incident solar radiation in 12 of the 14 channels during the flights on 12 and 14 January and in 13 channels on 16 January. This resulted in the retrieval of AOD values that were anomalously large in the affected channels and AOD spectra that were anomalously flat (for the frost-affected channels). Because there were no in-flight pictures of the quartz window, the magnitude and spectral shape of the retrieved AOD spectra were initially the only evidence that the anomaly might, in fact, be an instrumental problem. The problem was correctly diagnosed as frost on the window during the second Kiruna science flight (14 January), when in-flight instrument field of view (FOV) measurements yielded anomalous detector response curves, and pictures of the quartz window after the aircraft landed documented the presence of frost. The effect of frost can be modeled as a decrease in window transmission, but the actual magnitude and wavelength dependence of the attenuation attributable to the frost was unknown, so it was not possible to correct the affected data to retrieve accurate AODs. It is believed that the frost resulted from residual moisture within the instrument head. The problem was solved by more extensively purging the instrument head with dry nitrogen between flights. As described in a companion paper by Russell et al. (2005) in this issue, inflight FOV scans and post-acquisition diagnostic data analyses confirmed that window frost did not occur during subsequent flights.

AATS-14 acquired "frost-free" measurements in all channels during the sunlit portions of eight science flights during the mission. Table 1 lists the dates and times of measurements for these eight flights, which included one flight that was staged out of Edwards AFB prior to the aircraft deployment to Kiruna, Sweden, six flights out of Kiruna, and the return transit from Kiruna to Edwards AFB. AATS-14 samples at three Hz. Every four seconds it records data consisting of an average and standard deviation of nine samples taken during the first three of the four seconds. These data
Table 1. DC-8 flight dates and times of frost-free AATS-14 measurements during SOLVE II.

\begin{tabular}{cccc}
\hline Date $^{a}$ & Start time $^{b}$ & Stop time $^{b}$ & No. of measurements \\
\hline $19 / 12 / 2002$ & $21: 54: 00$ & $24: 52: 46$ & 2142 \\
$19 / 01 / 2003$ & $09: 27: 04$ & $13: 34: 19$ & 2720 \\
$21 / 01 / 2003$ & $12: 30: 15$ & $17: 46: 51$ & 4286 \\
$24 / 01 / 2003$ & $10: 34: 09$ & $12: 11: 32$ & 1163 \\
$29 / 01 / 2003$ & $10: 18: 00$ & $11: 27: 33$ & 717 \\
$31 / 01 / 2003$ & $08: 30: 14$ & $10: 03: 18$ & 1076 \\
$02 / 02 / 2003$ & $09: 54: 41$ & $12: 55: 36$ & 2364 \\
$06 / 02 / 2003$ & $15: 00: 03$ & $16: 49: 47$ & 1551 \\
\hline
\end{tabular}

a All dates in $\mathrm{dd} / \mathrm{mm} /$ yyyy format.

${ }^{b}$ All times in hh:mm:ss UT format.

are stored together with data on instrument tracking and temperature control, aircraft location, and ambient temperature, dewpoint, and static pressure. The standard deviations of all the channels are used subsequently in a cloud-screening algorithm, as described by Schmid et al. (2003). Data are transmitted serially from a computer within the instrument to a remote operator station (laptop computer). The science data are then combined with previously determined radiometric calibration values to calculate and display aerosol (particulate) optical depth, $\tau_{p}(\lambda)$, and columnar water vapor, CWV, in real time at the operator station.

Our methods for data reduction, calibration, and error analysis have been described in detail previously (Russell et al., 1993a, 1993b; Schmid and Wehrli, 1995; Schmid et al., 1996, 2001, 2003). The AATS-14 channels are chosen to permit separation of aerosol, water vapor, and ozone attenuation along the measured slant path. From these slantpath transmissions we can retrieve $\tau_{p}(\lambda)$ in 13 narrow wavelength bands (centered at 354, 380, 453, 499, 519, 604, 675, $778,865,1019,1241,1558$, and $2139 \mathrm{~nm}$, with full-widthhalf-maximum bandwidths of 2.0, 4.6, 5.6 5.4, 5.4, 4.9, 5.2, $4.5,5.0,5.1,5.14 .9$, and $17.3 \mathrm{~nm}$, respectively) and the columnar amounts of water vapor (from the channel centered at $941 \mathrm{~nm}$ ) and ozone. SOLVE II is the first mission in which the 2139-nm channel was flown, but these data will not be presented because we had not rigorously characterized gaseous absorption in that passband when the analysis for this manuscript was performed. In Fig. 1, the wavelengths of the AATS-14 channels are shown together with atmospheric attenuation spectra calculated using the Moderate Resolution Transmission (MODTRAN4v3.0) Code (Kneizys et al., 1996) for a view path from $10.4 \mathrm{~km}$ to the Sun at a solar zenith angle of $90^{\circ}$. This figure displays effective slant path optical thickness, $\ln (1 / \mathrm{T})$, where $\mathrm{T}$ is transmission, as a function of wavelength for the primary attenuating species, including Rayleigh and aerosol scattering, and gaseous absorption. It can be seen in Fig. 1 that, in addition 


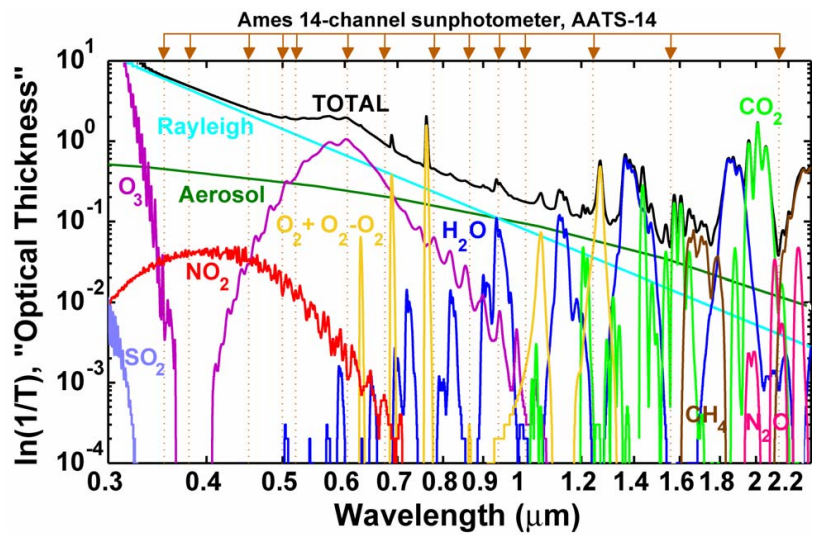

Fig. 1. Atmospheric attenuation ( $\mathrm{T}$ is transmission) spectra calculated using MODTRAN4v3.0 for a view path from $10.4 \mathrm{~km}$ to the Sun at a solar zenith angle of $90^{\circ}$. The passband centers of the AATS-14 channel filters are also shown.

to the corrections for Rayleigh scattering (for which the $\mathrm{Bu}$ choltz (1995) cross sections are used) and $\mathrm{O}_{3}$ absorption, measurements in some AATS-14 channels require corrections for $\mathrm{NO}_{2}, \mathrm{H}_{2} \mathrm{O}$ and $\mathrm{O}_{2}-\mathrm{O}_{2}$ absorption in order to retrieve AOD. Gas absorption cross-sections for the AATS14 channels were computed using LBLRTM 6.01 (Clough and Iacono, 1995) with the CKD 2.4.1 continuum model using the HITRAN 2000 (v11.0) line-list (Rothman et al., 2003) that includes an update for water vapor from April 2001. $\mathrm{NO}_{2}$ cross-sections not included in LBLRTM 6.01 were taken from Harder et al. (1997). For results in this paper $\mathrm{NO}_{2}$ column content was assumed constant at $2 \mathrm{x}$ $10^{15}$ molecules $\mathrm{cm}^{-2}$, which corresponds to optical depths of 0.0011 and 0.0008 in the $380-\mathrm{nm}$ and $453-\mathrm{nm}$ channels, respectively. Optical depth due to absorption by $\mathrm{O}_{2}-\mathrm{O}_{2}$ was less than 0.0002 in every channel except $1241 \mathrm{~nm}$, where the contribution was $\sim 0.0013$ for a flight altitude of $10 \mathrm{~km}$. Optical depth due to $\mathrm{H}_{2} \mathrm{O}$ absorption was negligible $\left(<5 \times 10^{-6}\right)$ in all aerosol channels (that is, excluding $941 \mathrm{~nm}$ ) for a flight altitude of $10 \mathrm{~km}$.

Calibration of AATS-14 was achieved by analysis of sunrise measurements acquired at Mauna Loa Observatory (MLO), Hawaii, for six sunrises in November 2002 prior to SOLVE II and for seven sunrises in March 2003 after SOLVE II. Exoatmospheric detector voltages, $V_{0}$, were derived using the Langley plot technique (e.g., Russell et al., 1993a, 1993b; Schmid and Wehrli, 1995) for all channels except $941 \mathrm{~nm}$, for which a modified Langley technique (Reagan et al., 1995; Michalsky et al., 1995; Schmid et al., 1996, 2001) was employed to account for water vapor absorption. In a manner analogous to that used by Schmid et al. (2003) in analyzing AATS-14 data acquired during the 2001 Asian Pacific Regional Aerosol Characterization Experiment (ACE-Asia), we used high altitude AOD spectra acquired during DC-8 flights in December 2002 to adjust the November MLO cali-

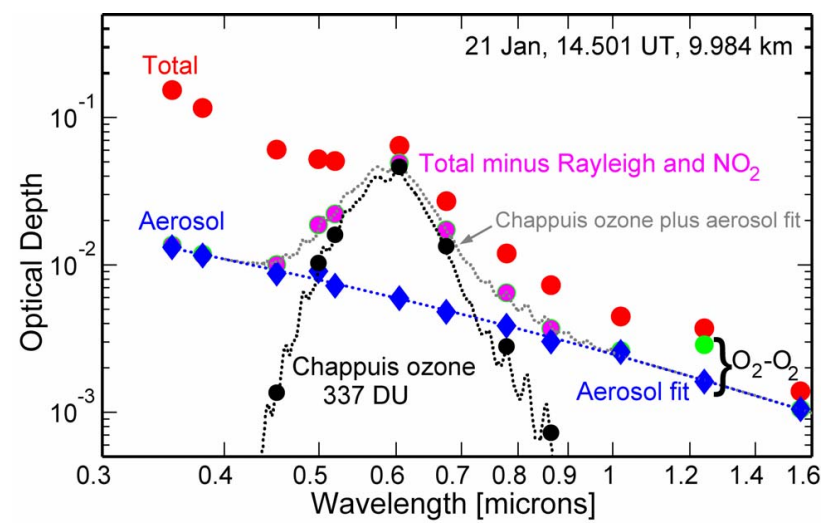

Fig. 2. Ozone retrieval methodology applied to optical depth spectrum measured by AATS-14 on 21 January 2003. The optimal least squares fit yields an ozone column content of 337 DU.

bration voltages for seven channels to yield "smooth" $\tau_{p}(\lambda)$ spectra. These adjustments were $<0.3 \%$ of the unadjusted November-March mean values for four channels $(675,778$, $1019,1240 \mathrm{~nm})$, and $0.6 \%(499 \mathrm{~nm}), 0.8 \%(1558 \mathrm{~nm})$, and $1.3 \%(864 \mathrm{~nm})$ of the unadjusted means for the remaining three channels. The adjusted November MLO $V_{0}$ values were used in the analysis of the December 2002 flights, but the final $V_{0}$ values applied to the January-February SOLVE II data set were simple arithmetic means of the adjusted November MLO values and the March MLO values. Corresponding $V_{0}$ uncertainties include statistical (sampling) errors that span the range of $V_{0}$ values included in the averages. Table 2 presents the MLO calibration results. With the exception of the 941-nm channel, sample standard deviations in $V_{0}$ were $\sim 0.3 \%$ or less in 12 of the 13 remaining channels for the November calibration data set, and $\sim 0.2 \%$ or less for all channels except $2139 \mathrm{~nm}$ for the March calibration data set. Most channels exhibited changes of less than $0.7 \%$ from November to March, but the 499-nm and 864-nm channels exhibited increases of $1.9 \%$ and $1.3 \%$, respectively.

\section{AATS-14 ozone retrieval methodology}

King and Byrne (1976) developed a weighted least squares method for retrieving columnar ozone $\eta$ from spectral solar irradiance measurements. Their method exploits the known spectral behavior of ozone absorption within the Chappuis absorption band (see Fig. 1) and assumes that the spectral variation in $\tau_{p}$ can be described by a quadratic fitting function of the form

$\log \tau_{p}(\lambda)=a_{0}+a_{1} \log \lambda+a_{2}(\log \lambda)^{2}$,

where $\lambda$ is wavelength and the $a_{i}$ are the fitting coefficients to be determined. Figure 2, which demonstrates the method, shows an example of Eq. (1) fitted to values determined from AATS-14 measurements on the DC- 8 flight of 21 January 
Table 2. Results of Langley plot analysis of AATS-14 measurements acquired during sunrises at Mauna Loa Observatory before and after SOLVE II. Mean and standard deviation of exoatmospheric detector voltages, $V_{0}$, are listed. November results include six sunrises; March results include seven sunrises.

\begin{tabular}{|c|c|c|c|c|c|c|c|c|c|c|c|c|c|c|}
\hline Wavelength(nm): & 353.5 & 380.0 & 452.6 & 499.4 & 519.4 & 604.4 & 675.1 & 778.4 & 864.5 & 940.6 & 1019.1 & 1241.3 & 1557.8 & 2139.3 \\
\hline \multicolumn{15}{|l|}{ November 2002} \\
\hline Mean: & 10.893 & 9.819 & 8.966 & 8.469 & 8.918 & 6.345 & 7.348 & 6.976 & 7.765 & 5.776 & 8.114 & 8.106 & 9.394 & 8.424 \\
\hline Relative SD (\%): & 0.23 & 0.46 & 0.21 & 0.31 & 0.11 & 0.18 & 0.14 & 0.21 & 0.13 & 2.84 & 0.14 & 0.08 & 0.10 & 0.13 \\
\hline \multicolumn{15}{|c|}{ Adjusted November 2002} \\
\hline Mean: & 10.893 & 9.819 & 8.966 & 8.511 & 8.918 & 6.345 & 7.333 & 6.986 & 7.866 & 5.776 & 8.098 & 8.122 & 9.470 & 8.424 \\
\hline \multicolumn{15}{|l|}{ March 2003} \\
\hline Mean: & 10.878 & 9.796 & 8.994 & 8.669 & 8.935 & 6.362 & 7.283 & 6.945 & 7.727 & 5.642 & 8.065 & 8.024 & 9.395 & 8.489 \\
\hline Relative SD (\%): & 0.20 & 0.23 & 0.15 & 0.13 & 0.12 & 0.08 & 0.14 & 0.06 & 0.13 & 1.71 & 0.08 & 0.12 & 0.10 & 0.27 \\
\hline \multicolumn{15}{|c|}{ Combined March and adjusted November } \\
\hline Mean: & 10.886 & 9.808 & 8.980 & 8.590 & 8.927 & 6.353 & 7.308 & 6.965 & 7.814 & 5.709 & 8.081 & 8.073 & 9.447 & 8.456 \\
\hline
\end{tabular}

2003. The King and Byrne method minimizes the statistic $\chi^{2}$ defined as

$\chi^{2}=\sum_{i} \frac{1}{\sigma_{i}^{\prime 2}}\left[\log \tau_{p}\left(\lambda_{i}, P, \eta\right)-a_{0}-a_{1} \log \lambda_{i}-a_{2}\left(\log \lambda_{i}\right)^{2}\right]^{2}$,

where the summation extends over all $\lambda_{i}$ for which no additional molecular absorption occurs, $\mathrm{P}$ is atmospheric pressure, and $\sigma_{i}$ are the standard deviations of the $\log \tau_{p}\left(\lambda_{i}, \mathrm{P}, \eta\right)$ values, or

$\sigma_{i}^{\prime 2}=\sigma_{i}^{2}\left[\frac{\log e}{\tau_{t}\left(\lambda_{i}\right)-\tau_{R}\left(\lambda_{i}, P\right)-\eta a\left(\lambda_{i}\right)}\right]^{2}$,

where $\tau_{t}$ is measured total optical depth, $\tau_{R}$ is calculated Rayleigh optical depth, $\sigma_{i}$ represents the uncertainty $\delta \tau_{p}\left(\lambda_{i}\right)$ in $\tau_{p}\left(\lambda_{i}\right)$, and $a\left(\lambda_{i}\right)$ is the ozone absorption coefficient at wavelength $\lambda_{i}$. Hence, the weighting factors $\sigma_{i}$ ' are proportional to the relative uncertainties in $\tau_{p}\left(\lambda_{i}\right)$. Unfortunately, as King and Byrne note, because $\sigma_{i}$ ' is a function of $\eta$, the set of equations that results after setting the partial derivative of $\chi^{2}$ with respect to each of the unknown coefficients $\left(a_{0}, a_{1}\right.$, $\mathrm{a}_{2}, \eta$ ) equal to zero is nonlinear in the coefficients. However, for a specific value of $\eta$, the set of simultaneous equations that results is linear in the unknowns $a_{0}, a_{1}, a_{2}$. Hence, the problem can be solved by varying the ozone column content $\eta$ until the minimum $\chi^{2}$ is found where $\partial \chi^{2} / \partial \eta$ equals zero, for which $\eta=\eta_{0}$. Finally, King and Byrne point out that, in practice, the uncertainty in $\tau_{p}\left(\lambda_{i}\right)$ can be approximated well by the measurement uncertainty in $\tau_{t}\left(\lambda_{i}\right)$ in the region of the minimum $\chi^{2}$.

King and Byrne applied their method to ground-based sunphotometer measurements taken in Tucson, Arizona under light to moderate aerosol loadings (King et al., 1980). Other methods for retrieving columnar ozone have also been reported in the literature. Flittner et al. (1993) applied a second-derivative smoothing approach to retrieve total ozone, and reported results comparable with those achieved with the King and Byrne approach when both were compared with TOMS overpass measurements. Taha and Box (1999) proposed a separate method, originally outlined by Box et al. (1996), based on an eigenvalue analysis for retrieving total column ozone. Unlike the King and Byrne approach, the Taha and Box method requires a priori assumptions of the type and optical properties of the aerosol in order to construct the kernel covariance matrix necessary for the eigenanalysis. They applied both methods to one year of daily measurements obtained at Sydney, Australia with a Multifilter Rotating Shadowband Radiometer (MFRSR) (Harrison et al., 1994) and found that the eigenanalysis gave better agreement with TOMS overpass ozone retrievals than the King and Byrne least squares method.

We have applied the King and Byrne method to the SOLVE II AATS-14 optical depth measurements. As shown in Fig. 1 and in Fig. 2, AATS-14 includes seven channels centered between 453 and $864 \mathrm{~nm}$ located within the Chappuis band, including one with its center wavelength $(604.4 \mathrm{~nm})$ near the peak, and three with center wavelengths (499.4, 519.4 and $675.1 \mathrm{~nm}$ ) where ozone absorption is $\sim 25-35 \%$ of that at the peak. For the typical DC- 8 SOLVE II cruising altitudes of $\sim 8-12 \mathrm{~km}$ and the background stratospheric aerosol conditions that prevailed during SOLVE II, ozone absorption comprised a significant fraction of the aerosol-plusozone optical depth measured in the four AATS-14 channels centered between 499.4 and $675.1 \mathrm{~nm}$. Typical AODs above the DC- 8 ranged from $0.003-0.009$ in these channels. For comparison, an ozone overburden of $0.3 \mathrm{~atm}-\mathrm{cm}$ (300 DU) translates to ozone optical depths of $0.009,0.014,0.041$, and 0.012 , respectively, at these same wavelengths. Prior to 
SOLVE II, we investigated the applicability of the Taha and Box (1999) method to synthetic SOLVE II AATS-14 measurements, but we found that their algorithm provided useful results only if the AATS-14 measurements were reduced to the wavelengths used in their paper.

\subsection{Dependence on relative optical airmass}

Accurate retrieval of columnar ozone and/or AOD depends critically on the use of appropriate relative optical airmass factors for all attenuating species along the instrument lineof-sight (LOS). Airmass is defined as the ratio of LOS optical thickness (OT) to vertical OT (i.e., OD) for any given constituent and/or wavelength. When SZA $>\sim 85^{\circ}$, as it was for most AATS-14 measurements in SOLVE II, airmass can be highly dependent upon the shape of the vertical distribution of the attenuating species (e.g., Thomason et al., 1983; Russell et al., 1993b). Hence, airmass uncertainties result from uncertainties in requisite assumed vertical profiles of number density or extinction or simply from lack of available data. Most AATS-14 measurements during SOLVE II were acquired at large solar zenith angles (SZA) near $90^{\circ}$, where refraction is significant and small changes in SZA can lead to large changes in airmass.

In our analysis of the SOLVE II AATS-14 data set, we have implemented a relatively new airmass algorithm (Yee et al., 2002; DeMajistre and Yee, 2002; Vervack et al., 2002) originally developed for inversion of combined extinctive and refractive stellar occultation measurements. We have modified the computer routine that implements the algorithm to accept user-input profiles of aerosol extinction and molecular and ozone number density. For flights out of Kiruna, we used profiles retrieved by the SAGE III or POAM III sensors during SOLVE II to calculate aerosol and ozone airmass, respectively. At altitudes below the lower limit of the satellite retrievals, the satellite-retrieved ozone profiles were combined with DC- 8 based in-situ measurements of ozone concentration obtained by the NASA Langley fast response chemiluminescent ozone sensor, FASTOZ (Avery et al., 2001; see also http://cloud1.arc.nasa.gov/ solveII/instrument_files/O3.pdf), during aircraft ascent immediately after takeoff from Kiruna at the start of each flight. For the December flights out of DFRC and the return transit flight from Kiruna to DFRC where measurements were taken at latitudes where no SAGE or POAM profiles were available, it was necessary to construct best estimate models of aerosol and ozone number density profiles from a mixture of climatological data, SAGE or POAM data taken at higher latitudes, and coincident lidar data when available. The MODTRAN subarctic winter model atmospheric density and water vapor profiles were used for calculating Rayleigh and water vapor airmass factors, respectively. Comparison of Rayleigh airmass factors calculated using the subarctic winter model with those derived from assimilated meteorological measurements (e.g., UKMO) generally yielded differences of $1 \%$ or less. The Yee et al. (2002) algorithm accounts for refraction of the incoming solar radiation by assuming horizontal homogeneity of attenuating species within atmospheric shells of specified thickness (typically, $0.5 \mathrm{~km}$ ). Recently, Swartz et al. $(2005)^{2}$ have modified the algorithm to account for threedimensional variations in species density along the viewing path, but our results did not use this formulation. The companion SOLVE II paper by Russell et al. (2005) presents input profiles and results from our application of the algorithm. In practice, we derived airmass factors for analyzing AATS14 data by using interpolation in matrices of airmass factors pre-calculated as a function of inertial SZA (at $0.1^{\circ}$ resolution) and aircraft altitude (at $0.5-\mathrm{km}$ resolution) for a particular SAGE or POAM occultation event. Russell et al. (2005) give details.

Our use of satellite profiles to derive the airmass factors provides a check on the mutual consistency of the sunphotometer and the satellite data sets. The most basic parameter that is calculated directly from the AATS-14 voltage measurement in each channel is slant path total solar transmission, which is just the measured detector voltage divided by the exoatmospheric detector voltage that was derived from the Mauna Loa measurements (corrected for the actual EarthSun distance at the time of observation). This AATS-14 measurement of slant path solar transmission is independent of airmass factor. We considered keeping the AATS-14 analyses wholly independent of the satellite results by reporting only AATS-14 path transmission or path ozone values, and comparing these to analogous path transmission or path ozone values computed from the satellite profiles for each AATS-viewed path. However, this would have produced results very unfamiliar to readers, since each would have depended on the viewing path for each individual AATS measurement. Since our goal is to provide a test of the consistency between the AATS and satellite ozone results, and since using satellite ozone relative vertical profiles to convert AATS path transmission to vertical column ozone does not invalidate this consistency check, we have chosen this approach in the interest of providing results (ozone vertical column content) more familiar to the typical reader. We stress that using satellite ozone relative vertical profiles to compute airmasses (used to convert AATS transmission to ozone vertical column content) does not invalidate the test of consistency between the satellite and AATS results-it just converts the test products into a more familiar form.

\footnotetext{
${ }^{2}$ Swartz, W. H., Yee, J.-H., and Randall, C. E.: Comparison of line-of-sight ozone column density with derived ozone fields and the effects of horizontal inhomogeneity, in preparation, 2005.
} 


\subsection{Uncertainty in ozone retrieval}

King and Byrne (1976) show that the variance in the derived ozone column content $\eta_{0}$ may be approximated by

$\sigma_{\eta_{0}}^{2} \approx \frac{1}{\sum_{i} \frac{a^{2}\left(\lambda_{i}\right)}{\sigma_{i}^{2}}}$

where, as noted above, $\sigma_{i}$ is the uncertainty $\delta \tau_{p}\left(\lambda_{i}\right)$ in $\tau_{p}\left(\lambda_{i}\right)$ and $a\left(\lambda_{i}\right)$ is the ozone absorption coefficient at wavelength $\lambda_{i}$. They note that if the absolute uncertainties are about the same at all wavelengths then the wavelengths with the largest ozone absorption have the largest influence on the variance, and that the magnitude of the absolute AOD error at that wavelength has nearly a linear effect on the magnitude of $\sigma_{\eta o}$. Their variance expression does not account for any uncertainty in the assumed ozone absorption spectroscopy. We show below that the uncertainty due to temperature dependence of the ozone absorption cross sections within the Chappuis band is probably negligible. Their variance expression assumes further that the uncertainties $\delta \tau_{p}$ are well characterized. There are a number of sources of $\delta \tau_{p}$ : uncertainties in instantaneous measured voltages $V\left(\lambda_{i}\right)$, calibration - i.e., exoatmospheric detector voltages $V_{0}\left(\lambda_{i}\right)$, airmass, Rayleigh optical depth, and gas absorber optical depths. For the bulk of our SOLVE II data, the effect of uncertainties in $V\left(\lambda_{i}\right)$ and $V_{0}\left(\lambda_{i}\right)$ on $\delta \tau_{p}$ is minimized because these uncertainties are inversely proportional to airmass (Russell et al., 1993a) and most of our measurements were acquired at large airmass values. However, for large airmass values, the uncertainties in airmass (Sect. 3.1) become relatively more significant, although we have made every effort to minimize these uncertainties through rigorous calculation of airmass factors, as described above. We believe the Rayleigh optical depth uncertainty is well known because we have an accurate measure of the ambient atmospheric pressure and the Rayleigh cross sections are well known. Because the ozone optical depth was a significant fraction of the total for the channels near the peak of the Chappuis band, the primary contributor to $\delta \tau_{p}$ in these channels is actually the uncertainty in the retrieved ozone column content, which depends critically on the use of correct airmass factors both for ozone and for aerosol and cannot be known a priori. In the absence of any available measurements of the vertical distributions of aerosol extinction and ozone number density, the choice (construct) of inappropriate models can lead to large errors in airmass and, hence, in the retrieved ozone and $\tau_{p}$.

We calculated ozone cross sections for the AATS-14 channels by convolving the AATS-14 filter functions with output from LBLRTM for a series of runs for a range of SZAs. Figure 3 shows the LBLRTM and the SAGE III database cross sections for the 590-615 nm wavelength region, which encompasses the peak of the Chappuis band, for temperatures of $220 \mathrm{~K}$ and $298 \mathrm{~K}$. We have overplotted our calculated cross section for the 604.4-nm AATS filter. Like the SAGE III in-

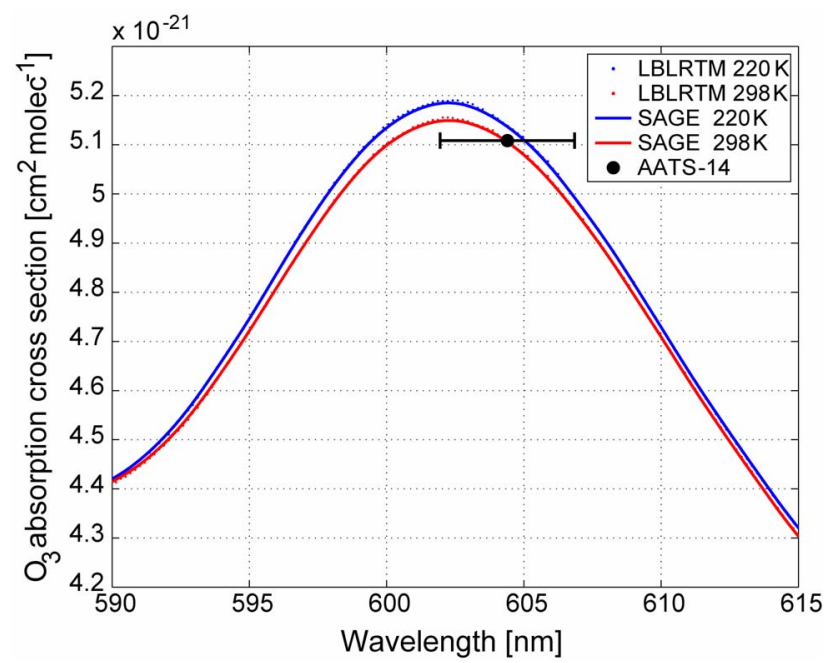

Fig. 3. Ozone cross sections from LBLRTM and the SAGE III database near the peak of the Chappuis absorption band. The black dot shows the value calculated by convolving the spectral response curve for the AATS-14 channel centered at $604.1 \mathrm{~nm}$ (with a FWHM of $4.9 \mathrm{~nm}$, as shown by the horizontal bar) with output from a series of LBLRTM runs for a range of SZAs.

version algorithm (NASA Langley Research Center, 2002), LBLRTM accounts for the temperature dependence of the ozone absorption cross sections by taking into account the distribution of ozone and atmospheric density along the LOS. As can be seen in Fig. 3, the temperature dependence of ozone absorption in the Chappuis band is small $(<1 \%$ near the peak, even for the large range of temperatures shown). In fact, for our retrievals, the temperature effect is negligible since the vertical distribution of ozone peaks at altitudes where the range of temperatures is significantly less than both the range shown in Fig. 3 and the variation of temperatures within those shells that account for most of the ozoneweighted path length along the LOS. For an ozone overburden of $0.3 \mathrm{~atm} \mathrm{~cm}(300 \mathrm{DU})$, even a $1 \%$ uncertainty in the assumed ozone cross section would result in a maximum uncertainty in retrieved columnar ozone of only 0.003 (3 DU) if the only AATS measurement used in the inversion were the 604-nm data, which is not the case.

Although most of our SOLVE II measurements were taken at large airmass values (typically $>28$ for aerosol and $>20$ for ozone), as noted above, we do present results for two flight segments where airmasses were $<10$ and as low as 3. As airmass decreases, uncertainties in $V_{0}\left(\lambda_{i}\right)$ become relatively more important and can lead to a significant bias in the retrieved ozone column. This bias does not seem to be captured adequately by the estimated variance expression (Eq. 3). We have quantified this effect empirically by comparing results from ozone retrievals performed for AATS14 data acquired at MLO with coincident columnar ozone measurements by Brewer and Dobson spectrometers. These 

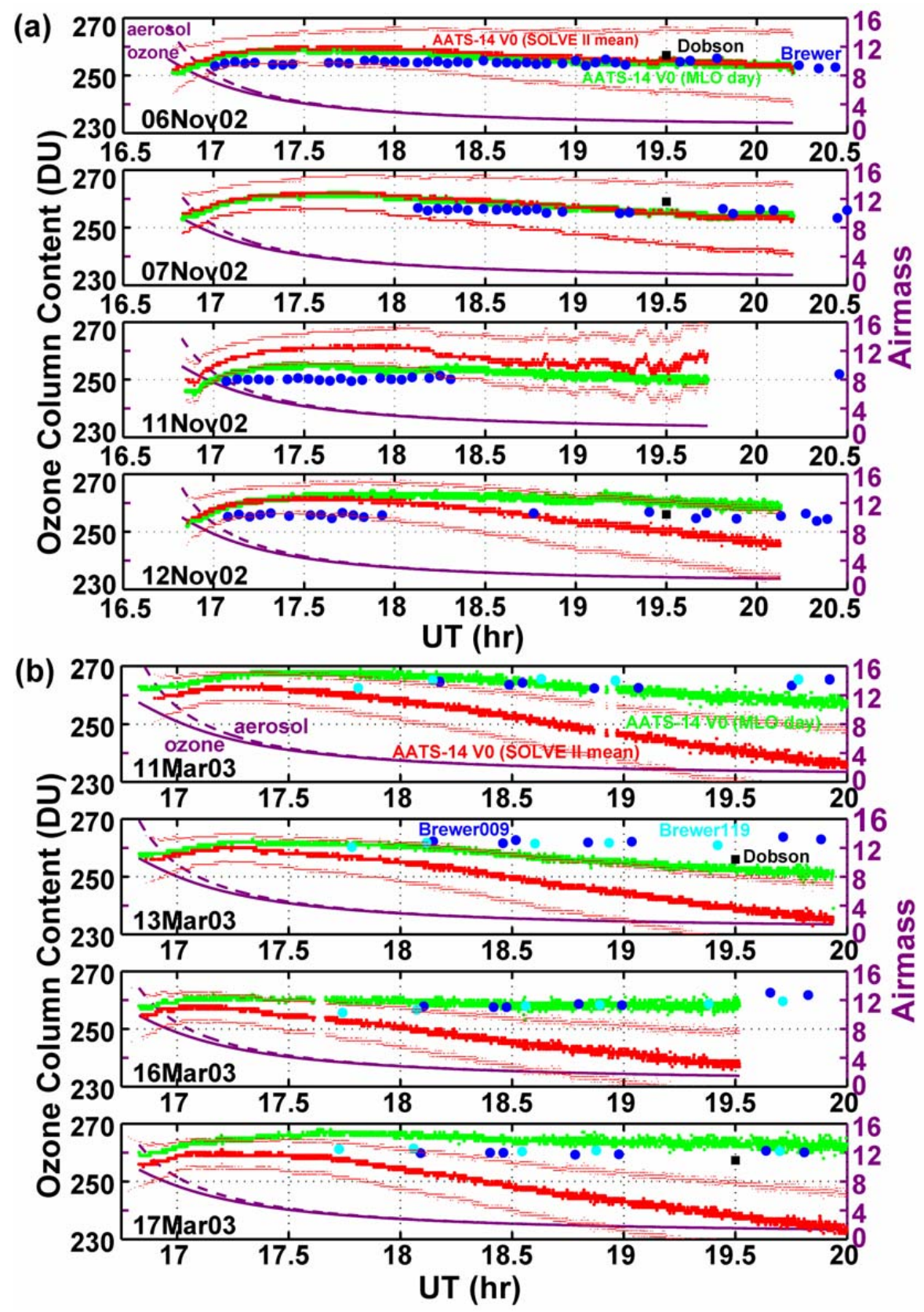

Fig. 4. Ozone column content retrieved from AATS-14 measurements after sunrise during instrument calibration at Mauna Loa Observatory, Hawaii in (a) November 2002 and (b) March 2003. Green points show retrievals that use exoatmospheric detector voltages (V0) calculated from the Langley plot analysis for the particular day; thick red points use the mean Vo values from the November and March data sets, and thin red points give the +- one standard deviation uncertainty returned by the fitting procedure. Coincident Brewer (blue and cyan) and Dobson (black) spectrometer ozone retrievals are also shown. Aerosol and ozone airmass values are plotted in purple.

results are presented in Fig. 4, which shows the temporal behavior of retrieved columnar ozone for four MLO sunrise calibration events each before (November 2002, Fig. 4a) and after (March 2003, Fig. 4b) SOLVE II. Results are shown for the case where the $V_{0}$ values derived from the Langley plot analysis (which used the measured Brewer or Dobson columnar ozone) for the particular day were used in the retrieval, and for the case where the mean $V_{0}$ values (mean of
March and adjusted November values) were used. For the latter, $\pm 1 \sigma$ uncertainties are also plotted. In addition, both the Brewer and the Dobson measurements and curves for ozone and aerosol airmass are also shown. AATS retrievals agree with the Brewer and Dobson measurements to better than $5 \mathrm{DU}$ when the calibration voltages for the specific day were used. When the mean SOLVE II calibration voltages are used, AATS retrievals for the November period also agree 

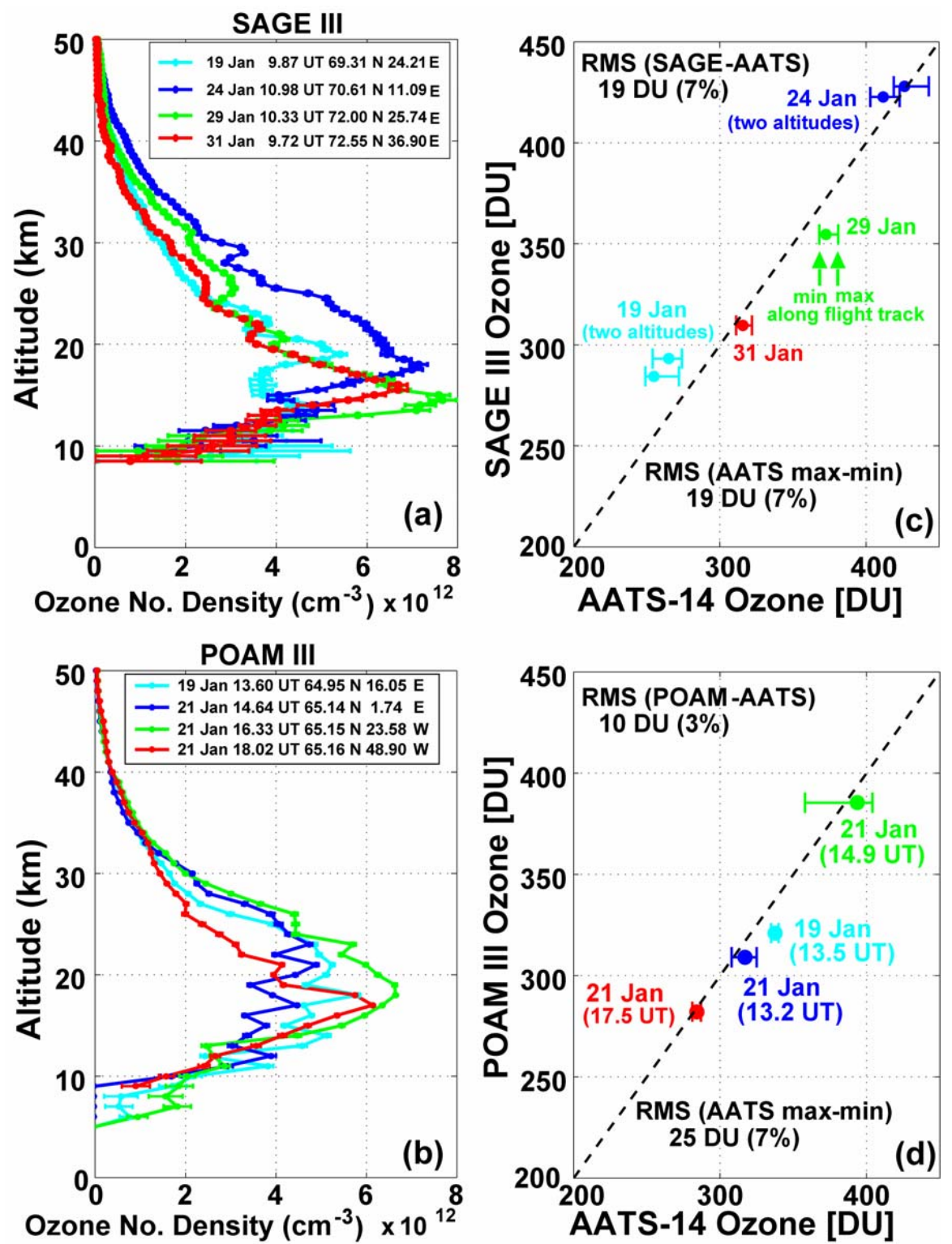

Fig. 5. SAGE III (a) and POAM III (b) ozone profiles; comparison of columnar ozone measured by (c) SAGE III and AATS-14 and (d) POAM III and AATS-14. Bars represent minimum and maximum AATS-14 retrievals along the DC-8 flight track.

with the corresponding Brewer/Dobson data to within about 5 DU. However, AATS retrievals for the March data set decrease markedly with decreasing airmass and significantly underestimate the Brewer/Dobson measurements (by up to 25 DU for an airmass of $\sim 2$ ). In summary, the apparent bias in retrieved ozone column content due to calibration uncertainty is negligible for large airmass values (e.g., near 20), a few DU for airmass factors $\sim 10$, but can be significant (up to $25 \mathrm{DU})$ for small airmass values $(<3)$.

\section{Measurement results}

\subsection{Comparison of AATS-14 with SAGE III and POAM III}

In this section, we compare AATS-14 retrievals of columnar ozone above aircraft altitude with near-coincident measurements by SAGE III and by POAM III for four occultation events each. The SAGE III occultation events occurred on four separate days: 19, 24, 29 and 31 Jan. The four POAM III events occurred on two days: 19 and 21 Jan. The satellite measurements obtained on 19 January are unsatisfactory for comparing SAGE to POAM, as they were separated by $\sim 600 \mathrm{~km}$ and $3.7 \mathrm{hr}$. For each occultation event, AATS-14 
Table 3. Times and locations of SAGE III and POAM III satellite occultation events coincident with DC-8 based AATS-14 measurements; AATS-14 data times with corresponding DC-8 altitudes, and DC-8 distances from sub-track satellite occultation tangent altitude point (SAGE $-10 \mathrm{~km}$, POAM $-20 \mathrm{~km})$.

AATS-14/SAGE III Coincidences

\begin{tabular}{|c|c|c|c|c|c|c|}
\hline DATE & $\begin{array}{r}\text { SAGE } \\
\text { UT } \\
(\mathrm{hr})\end{array}$ & $\begin{array}{l}\text { SAGE } \\
\text { Lat } \\
(\operatorname{deg})\end{array}$ & $\begin{array}{l}\text { SAGE } \\
\text { Lon } \\
(\operatorname{deg})\end{array}$ & $\begin{array}{l}\text { AATS } \\
\text { UT } \\
(\mathrm{hr})\end{array}$ & $\begin{array}{c}\text { DC-8 } \\
\text { Altitude } \\
(\mathrm{km})\end{array}$ & $\begin{array}{c}\text { Horizontal } \\
\text { Separation } \\
\quad(\mathrm{km})\end{array}$ \\
\hline 19 Jan & 9.87 & $69.31^{\circ} \mathrm{N}$ & $24.21^{\circ} \mathrm{E}$ & $\begin{array}{c}9.69-9.80 \\
10.32-10.62\end{array}$ & $\begin{array}{c}9.60-9.80 \\
10.41-10.45\end{array}$ & $\begin{array}{l}39-99 \\
12-99\end{array}$ \\
\hline 24 Jan & 10.98 & $70.61^{\circ} \mathrm{N}$ & $11.09^{\circ} \mathrm{E}$ & $\begin{array}{l}10.60-10.88 \\
11.00-11.50\end{array}$ & $\begin{array}{l}9.91-9.94 \\
8.71-8.76\end{array}$ & $\begin{array}{l}7-205 \\
3-178\end{array}$ \\
\hline 29 Jan & 10.33 & $72.00^{\circ} \mathrm{N}$ & $25.74^{\circ} \mathrm{W}$ & $10.13-10.43$ & $10.28-10.32$ & $20-100$ \\
\hline 31 Jan & 9.72 & $72.55^{\circ} \mathrm{N}$ & $36.90^{\circ} \mathrm{W}$ & $9.38-9.82$ & $9.05-9.08$ & $24-150$ \\
\hline
\end{tabular}

AATS-14/POAM III Coincidences

\begin{tabular}{clllccc}
\hline DATE & $\begin{array}{l}\text { POAM } \\
\text { UT } \\
(\mathrm{hr})\end{array}$ & $\begin{array}{l}\text { POAM } \\
\text { Lat } \\
(\mathrm{deg})\end{array}$ & $\begin{array}{l}\text { POAM } \\
\text { Lon } \\
(\mathrm{deg})\end{array}$ & $\begin{array}{c}\text { AATS } \\
\mathrm{UT} \\
(\mathrm{hr})\end{array}$ & $\begin{array}{c}\text { DC-8 } \\
\text { Altitude } \\
(\mathrm{km})\end{array}$ & $\begin{array}{c}\text { Horizontal } \\
\text { Separation } \\
(\mathrm{km})\end{array}$ \\
\hline 19 Jan & 13.60 & $64.95^{\circ} \mathrm{N}$ & $16.05^{\circ} \mathrm{E}$ & $13.10-13.22$ & $11.23-11.26$ & $18-59$ \\
21 Jan & 14.64 & $65.14^{\circ} \mathrm{N}$ & $1.74^{\circ} \mathrm{E}$ & $13.22-13.66$ & $9.94-9.95$ & $100-200$ \\
21 Jan & 16.33 & $65.15^{\circ} \mathrm{N}$ & $23.58^{\circ} \mathrm{W}$ & $14.92-15.43$ & $9.96-9.98$ & $224-300$ \\
21 Jan & 18.02 & $65.16^{\circ} \mathrm{N}$ & $48.90^{\circ} \mathrm{W}$ & $17.53-17.61$ & $11.16-11.18$ & $48-60$ \\
\hline
\end{tabular}

retrievals have been averaged during time periods when the DC-8 flew at constant altitude, and the near-coincident satellite profile of ozone number density has been integrated from the aircraft altitude to the top of the profile. Table 3 lists the times and locations of the satellite observations, and the range of AATS-14 measurement times, DC- 8 altitudes, and horizontal distances from the DC-8 to the sub-orbital satellite LOS tangent point corresponding to the AATS-14 data included in each average. As can be seen in Table 3, all AATS14 measurements used in the SAGE comparisons were acquired within 45 minutes of the corresponding SAGE observation, and they were separated by no more than $\sim 200 \mathrm{~km}$ from the SAGE 10-km LOS tangent point. AATS-14 data used in the POAM comparisons were separated from the POAM 20-km LOS tangent point by a few minutes to a maximum of $\sim 1.5 \mathrm{~h}$ and by $20-300 \mathrm{~km}$.

Figure 5 shows the measured satellite ozone number density profiles and corresponding scatterplots of satellite versus AATS retrieved column ozone. The AATS mean ozone value along the flight track during each time period is plotted with a color-coded (by date) dot, and the range (vari- ability) of AATS values along the flight track is shown with a horizontal bar. For the SAGE/AATS comparison, separate values are given for two aircraft altitudes (lower limit of integration for the SAGE profile) for the 19 January and 24 January events. Mean differences are 7.7 DU (3.1\%) for (SAGE-AATS)/AATS and -8.7 DU $(-2.5 \%)$ for (POAMAATS)/AATS comparisons. Corresponding RMS differences are 19DU (7\%) for (SAGE-AATS)/AATS and $10 \mathrm{DU}$ (3\%) for (POAM-AATS)/AATS comparisons. As shown by the horizontal bars in Fig. 5, spatial variability along the AATS flight track is likely a significant contributor to these RMS differences.

This spatial variability is evident in Fig. 6, which examines the 24 January case in more detail. The temporal variation in AATS AOD is presented in Fig. 6a for the time period 9.812.2 UT, and the corresponding variation in vertical columnar ozone, aircraft altitude, and SZA is shown in Fig. 6b. The SAGE III solar occultation occurred at 10.98 UT. AATS LOS ozone values (airmass times vertical column ozone) are overplotted with coincident DIAS ozone retrievals and with GAMS relative ozone retrievals (derived from measurements 

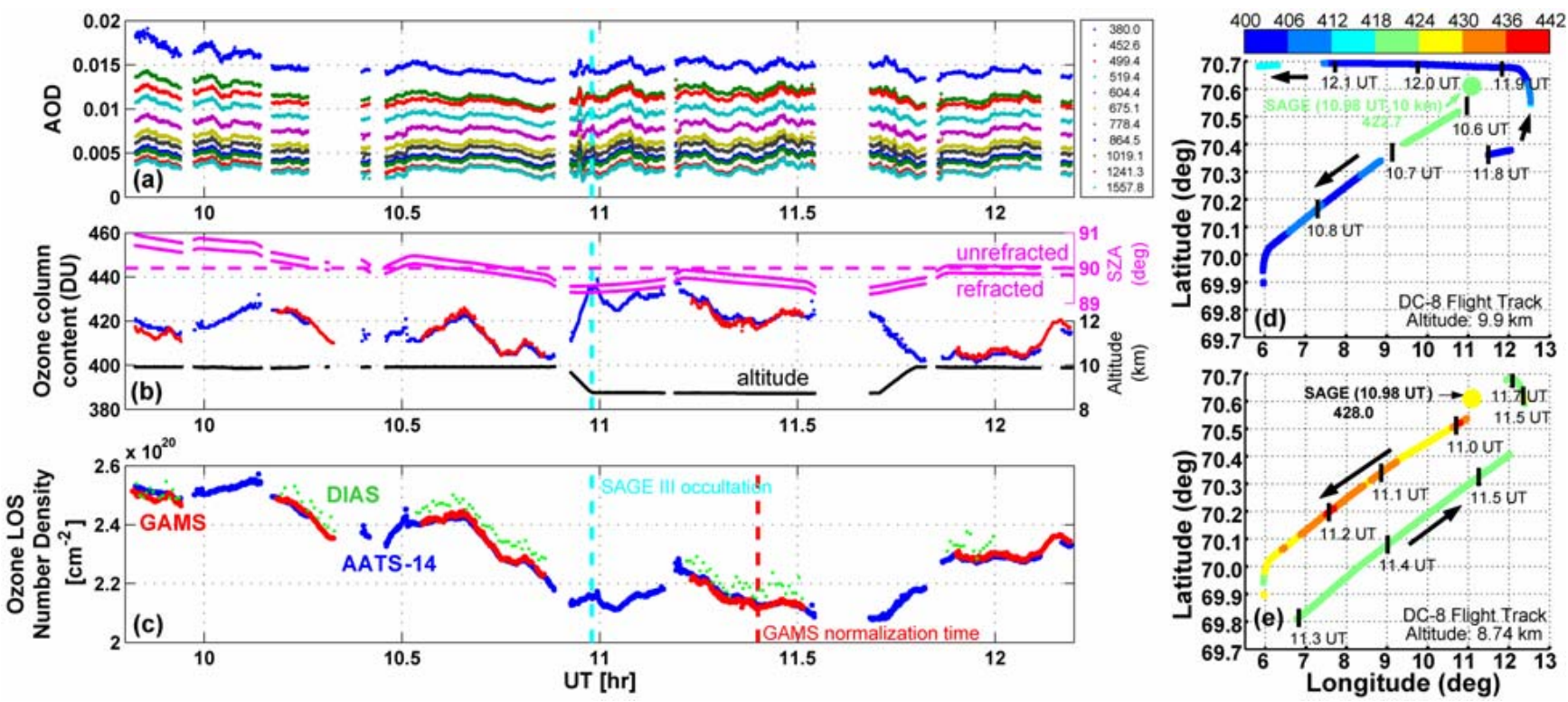

Fig. 6. Frames (a) and (b) show the variation in AOD and columnar ozone, respectively, measured by AATS-14 during the 24 January 2003 flight. Corresponding GAMS retrievals are also shown in (b), and AATS-14, DIAS, and GAMS retrievals of ozone number density along the line of sight (LOS) are plotted in (c). Rms differences are $\sim 2.1 \%$ for AATS and DIAS, and $\sim 0.5 \%$ for AATS and GAMS. In (d) and (e), the spatio-temporal variation in AATS-14 columnar ozone along the DC-8 flight track is shown for data acquired at flight altitudes of $9.9 \mathrm{~km}$ (10.6-10.9 UT and 11.8-12.2 UT) and $8.74 \mathrm{~km}$ (11.0-11.7 UT), respectively. Values are consistent with the integrated 10.98 UT SAGE III retrieval (color coded dot).

acquired at two different solar zenith angles and normalized to AATS values at $11.4 \mathrm{UT}$ ) in Fig. 6c. Mean (AATSDIAS)/AATS differences are $-1.75 \%$, with an RMS difference of $2.1 \%$. Mean (AATS-GAMS)/AATS differences are $0.1 \%$, with an RMS difference of $0.5 \%$. The largest differences occurred during the period before $10 \mathrm{UT}$, when SZAs exceeded $90^{\circ}$.

Figure 6d shows the variation in AATS-retrieved columnar ozone along the DC-8 flight track above the DC-8 flight altitude of $9.9 \mathrm{~km}$. It includes data from two flight segments, 10.6-10.9 UT and 11.8-12.2 UT, as shown in Fig. 6b. Only data acquired during the first flight segment (which is closer to the SAGE III occultation time of $10.98 \mathrm{UT}$ ) were averaged for the 9.9-km data point shown in Fig. 5c. The location of the SAGE III 10-km tangent altitude suborbital location is shown in Fig. 6d with a large dot that is color coded to reflect the SAGE III columnar ozone value of 422.7 DU, which was calculated by integrating the SAGE III ozone number density profile above $9.9 \mathrm{~km}$. Corresponding AATS-14 retrievals range from 401 to 423 DU for the two flight segments, with the maximum measured at $\sim 10.65$ UT just to the southwest of the SAGE tangent location. The AATS-14 columnar ozone retrieval at the 9.9-km altitude DC-8 location closest in time $(\sim 10.6 \mathrm{UT})$ and space $(\sim 8 \mathrm{~km})$ to the SAGE III $10-\mathrm{km}$ tangent point is $417 \mathrm{DU}$, or $\sim 6 \mathrm{DU}(1.3 \%)$ less than the SAGE III result.
Figure 6e presents analogous AATS-14 results for measurements acquired at an altitude of $\sim 8.74 \mathrm{~km}$ during the 10.98-11.71 UT period. These data are included in Fig. 5c as a separate data point. During this flight segment AATS ozone retrievals for measurements closest in time and space to the SAGE III 10-km tangent location were 436 DU. The lower limit of the SAGE III retrieval was $9.5 \mathrm{~km}$, and the integrated value above this altitude was 425 DU. Assuming a constant ozone density between $8.74 \mathrm{~km}$ and $9.5 \mathrm{~km}$ equal to the SAGE retrieval at $9.5 \mathrm{~km}$ yields a columnar ozone value of $428 \mathrm{DU}$ above $8.74 \mathrm{~km}$, or $8 \mathrm{DU}(1.8 \%)$ less than the AATS-14 8.74-km result (436 DU) closest in time and space to SAGE III.

\subsection{Comparison of AATS-14 with GOME and TOMS}

In this section, we compare values of overlying columnar ozone retrieved from AATS-14 measurements acquired during extended horizontal transects during three flights (1920 December, 21 January, 6 February) with corresponding TOMS and GOME total ozone column retrievals. For TOMS, the Version 8 (V8) Level-3 global gridded $\left(1^{\circ}\right.$ latitude by $1.5^{\circ}$ longitude) daily mean product (McPeters et al., 1998) has been used. For GOME, one or both of the harmonic analysis daily mean product or the Kalman-filtered assimilated product (Bittner et al., 1997; Meisner et al., 1999) has/have been used. 
In order to compare the AATS retrievals with the total column satellite retrievals, it is necessary to estimate the amount of ozone below the aircraft altitude. We have made this estimate in two ways: by using an assumed climatological model (either the 1976 standard atmosphere ozone model or a seasonal/latitudinal ozone model (McPeters et al., 2003) which is a composite of balloon, SAGE I and SAGE II measurements), and/or by incorporating in-situ data obtained by the FASTOZ instrument during DC-8 ascent at the beginning or aircraft descent at the end of each science flight. Typically, the FASTOZ profiles were separated from the satellite observations by several hours. The relative contribution of the amount of ozone below the aircraft to the total column will be discussed in the case analyses below.

\subsubsection{DC-8 Longitudinal Transect on 21 January 2003}

Figure 7 presents results from the DC-8 flight from Sweden to Greenland on 21 January. Corresponding TOMS and GOME total column ozone retrievals are shown in color contour maps in Fig. 7a and b, respectively, and the DC-8 flight track is overplotted in magenta. The GOME data represent the daily harmonic retrieval product.

Figure $7 \mathrm{c}$ compares ozone retrievals by AATS-14 with those from the satellite sensors. At DC- 8 flight locations between $16^{\circ} \mathrm{W}$ and $56^{\circ} \mathrm{W}(14.6-17.1 \mathrm{UT})$ columnar ozone retrievals by the three DC- 8 solar occultation sensors (AATS14, DIAS, and GAMS) are in good agreement, with RMS differences of $<1 \%$ of the AATS value for AATS-DIAS and $\sim 1.5 \%$ for AATS-GAMS. DIAS retrievals are shown in Fig. 7c, but GAMS results are not presented here. LOS retrievals from measurements acquired by all three DC- 8 solar occultation sensors during this flight can be found in Pitts et al. (2005) ${ }^{1}$. For comparison of AATS-14 results with GOME and TOMS total column retrievals, the ozone distribution below aircraft altitude has been assumed equal to that measured by FASTOZ during the DC-8 ascent out of Kiruna, and an amount equal to the integral of the FASTOZ measurements between the surface and the aircraft altitude has been added to each AATS-14 ozone retrieval. The resultant values are displayed in Fig. $7 \mathrm{c}$ with a thick black line. The amount of ozone below the aircraft increased the AATS-14 retrievals by $\sim 6.5-12 \%$ ( $20-37 \mathrm{DU})$, which was $\sim 7-13.7 \%$ of the total columnar ozone. Corresponding GOME and TOMS retrievals are shown in Fig. 7c for comparison. Only TOMS data for grid points located within $120 \mathrm{~km}$ of the DC8 flight track have been included in the comparison. Satellite and DC- 8 based results appear mutually consistent, in light of the different spatial and temporal resolutions of the measurements. The RMS difference between AATS-14 and GOME retrievals interpolated to the DC- 8 flight track is $3.3 \%$ (12 DU).

DC- 8 based solar occultation measurements during the 21 January flight were obtained at refracted SZAs that ranged from $\sim 84^{\circ}$ to $\sim 89^{\circ}$ (Fig. 7 d), with SZAs less than $87^{\circ}$ over the longitude range $\left(0-50^{\circ} \mathrm{W}\right)$ for which GOME retrievals were available along the DC-8 flight track. These values represented the smallest SZAs during any of the Kirunabased science flights. For analysis of the AATS-14 measurements, ozone airmass factors were calculated using a single profile constructed from the FASTOZ measurements taken below $10 \mathrm{~km}$ during the ascent $\left(12.2 \mathrm{UT}, 67.8^{\circ} \mathrm{N}, 20.3^{\circ} \mathrm{E}\right.$ to $12.8 \mathrm{UT}, 67.2^{\circ} \mathrm{N}, 12.8^{\circ} \mathrm{E}$ ) after takeoff from Kiruna and from the SAGE III ozone retrieval at and above $10 \mathrm{~km}$ for the 12.77 UT $\left(69.77^{\circ} \mathrm{N}, 19.19^{\circ} \mathrm{W}\right)$ occultation. Aerosol airmass factors were calculated using POAM III aerosol extinction retrievals from the $18.02 \mathrm{UT}\left(65.16^{\circ} \mathrm{N}, 48.90^{\circ} \mathrm{W}\right)$ satellite solar occultation event. Ozone airmasses ranged from $\sim 8.0$ 17.3 , and aerosol airmasses ranged from $\sim 8.6-35.4$. Russell et al. (2005) show time series of these airmasses.

\subsubsection{DC-8 Latitudinal Transect on 19-20 December 2002}

On 19 December 2002, the DC-8 flew a roundtrip latitudinal transect from Edwards AFB $\left(34.96^{\circ} \mathrm{N}, 117.78^{\circ} \mathrm{W}\right)$ to $22.6^{\circ} \mathrm{N}, 116.1^{\circ} \mathrm{W}$. As shown in Fig. 8, the flight track was designed to traverse the subtropical jet core and include a short segment in stratospheric air near $31^{\circ} \mathrm{N}$ during the southward transect, which was flown at altitudes between 10.1 and $10.5 \mathrm{~km}$, and a longer segment in the stratosphere north of $\sim 30^{\circ} \mathrm{N}$ during the northward transect, which was flown at altitudes between 12.4 and $12.1 \mathrm{~km}$. During the southbound flight segment AATS-14 data were acquired at SZAs that increased from $63.8^{\circ}$ at $33.5^{\circ} \mathrm{N}(21.9 \mathrm{UT})$ to $70.3^{\circ}$ at the southernmost point of $22.6^{\circ} \mathrm{N}$ (23.3 UT). During sunset on the northbound return segment AATS-14 successfully tracked the sun down to a SZA of $91.2^{\circ}\left(\sim 31.3^{\circ} \mathrm{N}, 25.0 \mathrm{UT}\right)$. However, due to uncertainties in ozone and aerosol airmass factors, AATS-14 ozone retrieval results are presented in Fig. 9 only for SZAs $<89^{\circ}$, and they are compared with corresponding TOMS and GOME retrievals and with smoothed (using a five-point running mean filter on data at 30-s resolution) DIAS measurements, which were obtained only during the northbound segment. DIAS columnar ozone results were calculated from the DIAS LOS ozone retrievals by applying the same ozone airmass factors that were used in the analysis of AATS-14 data. DIAS and AATS-14 columnar ozone results agree to within $1 \%$. No GAMS data are available for this flight. For direct comparison with TOMS and GOME total column amounts, the AATS retrievals have been increased by an amount of ozone (23-26 DU) below aircraft altitude that has been estimated using the McPeters et al. (2003) climatological results for December, $20^{\circ}-30^{\circ} \mathrm{N}$. These contributions represented $\sim 7.5-10 \%$ of the total columnar ozone.

AATS-14 retrievals indicate a decrease of $\sim 40 \mathrm{DU}$ above the aircraft between $33^{\circ} \mathrm{N}$ and $23^{\circ} \mathrm{N}$ during the southward transect, including a decrease of $\sim 20 \mathrm{DU}$ between $30^{\circ} \mathrm{N}$ and $23^{\circ} \mathrm{N}$. A slightly larger increase was found over this same latitude range during the northbound return at the higher altitude. AATS-14 and DIAS retrievals agree to within a few DU 

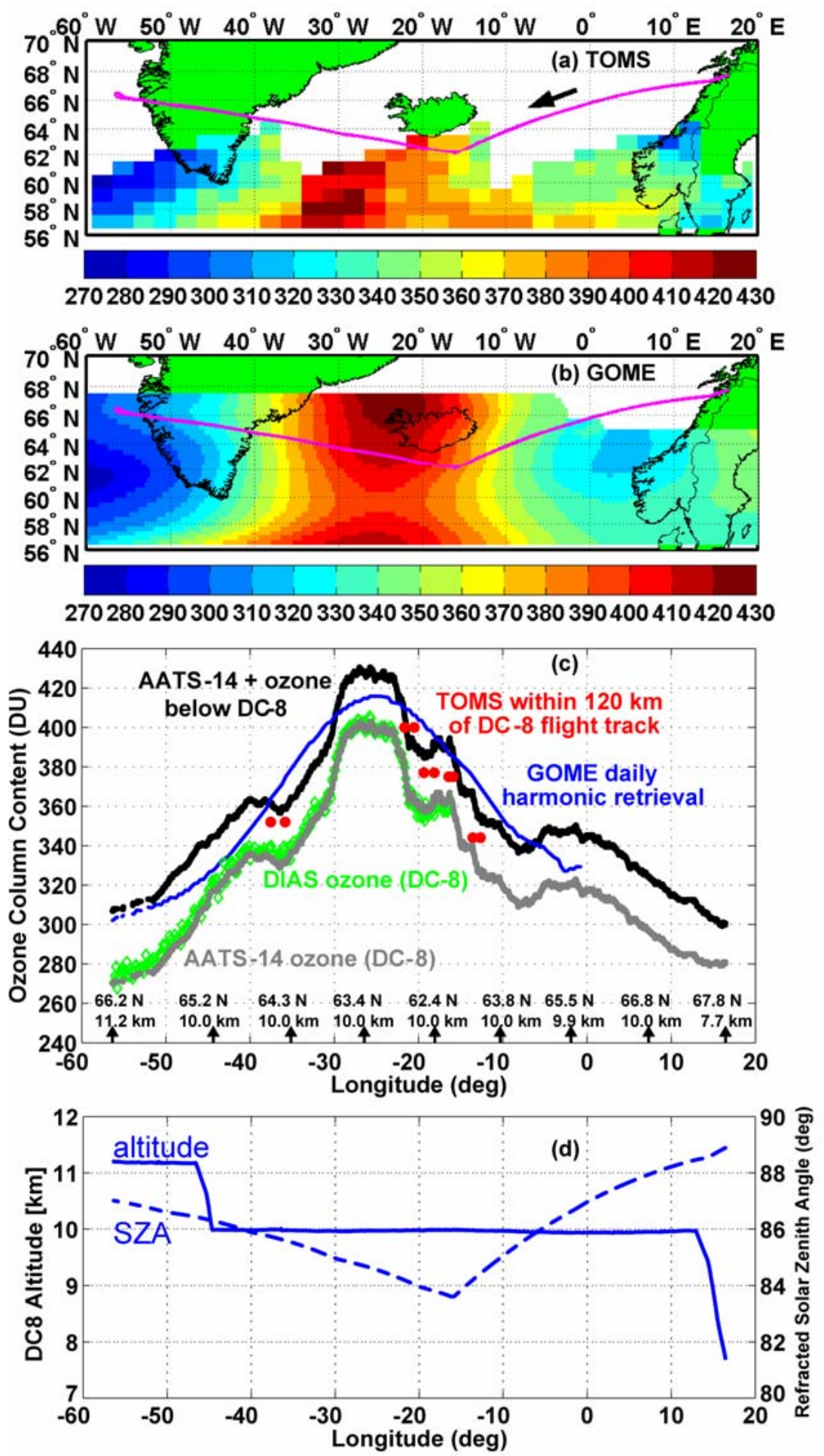

Fig. 7. Comparison of columnar ozone retrieved from AATS-14 measurements during an extended horizontal transect by the DC- 8 on 21 January 2003. Contours of ozone column content retrieved from (a) TOMS and (b) GOME measurements overplotted on the DC-8 flight track (magenta). Comparison of AATS-14 (gray) and DIAS (green) ozone above DC-8 altitude, and AATS-14 (black) with along-track GOME (blue) and near-track TOMS (red) total column ozone in (c). Solar zenith angle (dashed) and DC-8 altitude (solid) are shown in (d). 


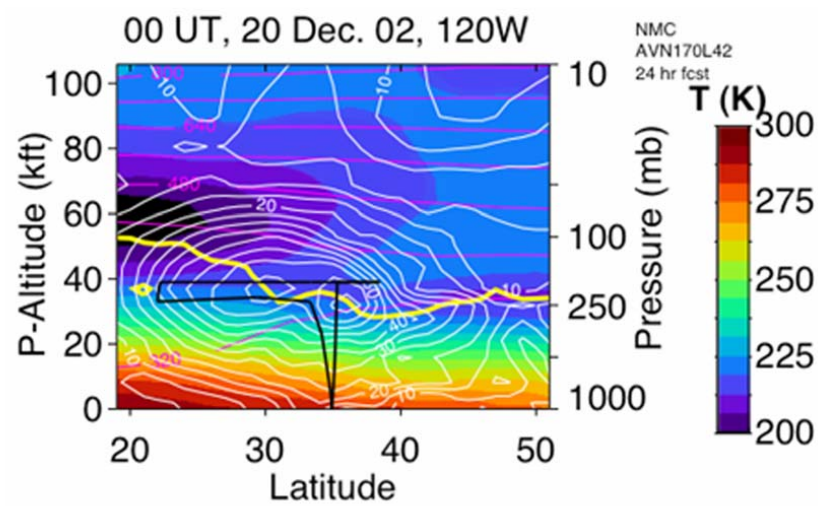

Fig. 8. Planned 19-20 December 2002 DC-8 flight track (solid black) overplotted on 24-h NMC AVN forecast of winds (white contours), isentropic surfaces (magenta lines), and tropopause location (solid yellow line) along $120^{\circ} \mathrm{W}$ longitude. The DC-8 southbound transit was at the lower altitude. Maps were produced by L. Lait, M. Schoeberl, and P. Newman.

except near the boundaries of the DIAS data, where larger differences lead to a composite RMS difference of 5.8 DU. Corresponding TOMS and GOME retrievals interpolated to the DC- 8 flight track are shown for different time periods that encompass the DC- 8 flight times. The daily mean TOMS retrievals show an increase of $\sim 10-30$ DU at similar latitudes north of $27^{\circ} \mathrm{N}$ between 19 and 20 December. The GOME data, which include the harmonic analysis retrievals for 19 and 20 December (labeled 12 UT), and the Kalman-filtered product for 23 UT 19 December, reflect a much smaller increase ( $\sim 10 \mathrm{DU})$ in columnar ozone north of $28^{\circ} \mathrm{N}$ than reported by TOMS.

Retrievals from both satellites exhibit the same general latitudinal behavior - namely, higher ozone to the north, as observed by AATS-14. However, after correction for an estimated amount of ozone below aircraft altitude, the AATS-14 data exceed GOME and TOMS 19 December data by $\sim 20$ $30 \mathrm{DU}$ at all latitudes, but agree to within $10 \mathrm{DU}$ or less with 20 December TOMS data north of $28^{\circ} \mathrm{N}$.

The DC- 8 based NASA Langley Differential Absorption Lidar (DIAL) instrument (Browell et al., 1998; Grant et al., 1998) measured ozone concentrations at altitudes between 14 and $26 \mathrm{~km}$ during the northbound transect for latitudes north of $25^{\circ} \mathrm{N}$. The lidar data indicate an increasing ozone concentration to the north above $20 \mathrm{~km}$, with a broad peak in concentration centered at $\sim 22 \mathrm{~km}$ altitude north of $\sim 29.4^{\circ} \mathrm{N}$. Because the lidar data cover a limited vertical range, vertical integration of the lidar data set yields layer ozone values much less than the columnar content (above the aircraft) measured by AATS and DIAS. However, the lidar data are extremely useful because they provide the only measurement of the vertical distribution of ozone through the peak of the stratospheric ozone layer along the DC-8 flight track. The data have been combined with the McPeters et al. (2003) climatological ozone profile at altitudes above and below to construct a composite profile that was used to calculate ozone airmass values that best reflect the actual vertical distribution of ozone in that region.

\subsubsection{DC-8 Transit from Kiruna to DFRC on 6 February 2003}

Figure 10 compares AATS-14 and DIAS ozone retrievals from measurements acquired during the final segment of the DC-8 transit back to California on 6 February with TOMS and GOME values. AATS-14 results are shown for data acquired during the period 15.0-16.8 UT, when SZAs decreased from $90^{\circ}$ just south of the U.S./Canada border to $68.5^{\circ}$ upon landing at Edwards AFB. This corresponded to ozone airmasses of 16 to 2.6. DIAS data are only available as far south as $37^{\circ} \mathrm{N}$. Again, DIAS columnar ozone results were calculated from the DIAS LOS retrievals by applying the same ozone airmass values used in the AATS14 data analysis. The mean (AATS-DIAS)/AATS difference was $0.6 \%$, with an rms difference of $2.3 \%$. AATS- 14 values are shown with dark blue and red symbols, respectively, for data acquired at about $12.4 \mathrm{~km}$ constant altitude and during the descent into Edwards AFB. The thick yellow line shows AATS-14 results obtained by adding an estimated amount of ozone below DC-8 altitude by using FASTOZ measurements during descent into DFRC or the 1976 standard atmosphere ozone model profile after normalization to AATS-14 inferred columnar ozone above aircraft altitude. AATS retrievals show a distinct peak in columnar ozone of $\sim 470 \mathrm{DU}$ above the aircraft $(12.3-12.5 \mathrm{~km})$ from $45^{\circ}$ to $40^{\circ} \mathrm{N}$, and a sharp latitudinal gradient with a minimum value of $\sim 290 \mathrm{DU}$ at $35.5^{\circ} \mathrm{N}$. During the descent from $12.5 \mathrm{~km}$ to $1.1 \mathrm{~km}$ (altitude of Edwards AFB) AATS observed a $60 \mathrm{DU}$ increase in ozone to $\sim 350 \mathrm{DU}$.

Gridded data from TOMS and GOME have been interpolated to the locations of the DC-8 flight track. Two sets of GOME retrievals are shown: the 12 UT harmonic analysis composite product, and the 18 UT Kalman filter data assimilation. The composite retrieval resolves more of the latitudinal variation than does the Kalman product. The agreement between the latitudinal variation in columnar ozone measured by AATS retrievals and that measured by both TOMS and GOME retrievals is striking. After correcting AATS values for the amount of ozone below the aircraft (42-58 DU, representing $\sim 11-13 \%$ of the total column, for the DC- 8 maximum altitude of $12.4 \mathrm{~km}$ ), AATS and TOMS retrievals agree to better than $10 \mathrm{DU}$, except at the surface, where the AATS value of $350 \mathrm{DU}$ is about $30 \mathrm{DU}$ greater than the interpolated TOMS value. Upon landing, the ozone airmass value was 2.6, which, in light of the uncertainty discussion in Sect. 3.2 above, could result in an uncertainty in the AATS value measured at the surface of up to $25 \mathrm{DU}$.

The descent into Edwards AFB permitted a direct comparison of coincident AATS-14 and FASTOZ measurements. 

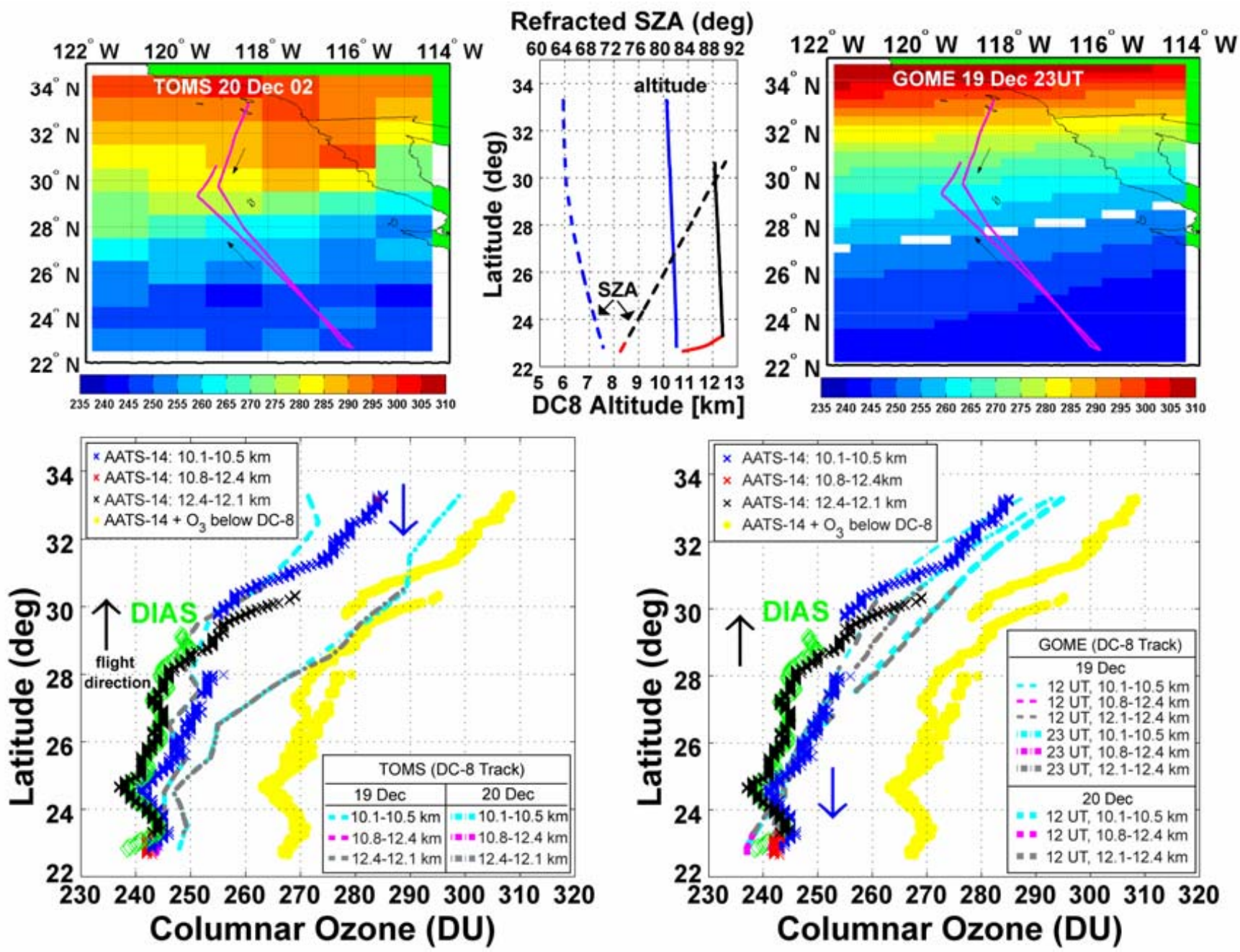

Fig. 9. Comparison of AATS and DIAS columnar ozone retrievals for DC-8 flight of 19-20 December 2002 with corresponding TOMS and GOME retrievals. The actual DC-8 flight track (magenta) is overplotted on contours of TOMS and GOME columnar ozone in the left and right upper frames; the upper middle frame shows the refracted SZA and DC- 8 altitude during the southbound transit (blue), the climb from $10.8 \mathrm{~km}$ to $12.4 \mathrm{~km}$ altitude at the southernmost point (red), and the northbound transit (black). The same color scheme is used for the AATS-14 ozone retrievals shown in the lower frames. The yellow points show AATS ozone retrievals plus an estimated ozone amount below DC-8 altitude.

Two approaches have been taken. Columnar ozone values are compared in Fig. 11a and ozone concentrations in Fig. 11b. In Fig. 11a, the FASTOZ ozone column at $12.2 \mathrm{~km}$ has been set equal to the AATS-14 ozone overburden retrieved at that altitude. The AATS-14 retrieval overestimates the amount of ozone between 12.1 and $1.6 \mathrm{~km}$, as measured by FASTOZ, by $\sim 12$ DU (or $3.22 \times 10^{17} \mathrm{~cm}^{-2}$ ). In Fig. $11 \mathrm{~b}$, differentiation of a spline fit to the AATS-14 columnar ozone profile, shown in Fig. 11a, yields a vertical profile of ozone concentration that is unable to reproduce the fine-scale structure measured by FASTOZ. This result is not surprising, as ozone concentration is a second order product of the AATS-14 ozone retrieval.

\section{Summary and Conclusions}

Measurements with AATS-14 during DC-8 flights in SOLVE II have been analyzed using least squares methodology to retrieve values of columnar ozone above aircraft altitude. These values have been compared with ozone retrievals from coincident or near-coincident measurements by SAGE III, POAM III, GOME, and TOMS, and with coincident ozone retrievals from the other two DC-8 based solar occultation instruments, DIAS and GAMS.

AATS-14 measurements were acquired during four SAGE III and four POAM III solar occultation events. Comparison of AATS-14 columnar ozone retrievals with corresponding values obtained by integrating the satellite retrievals of 

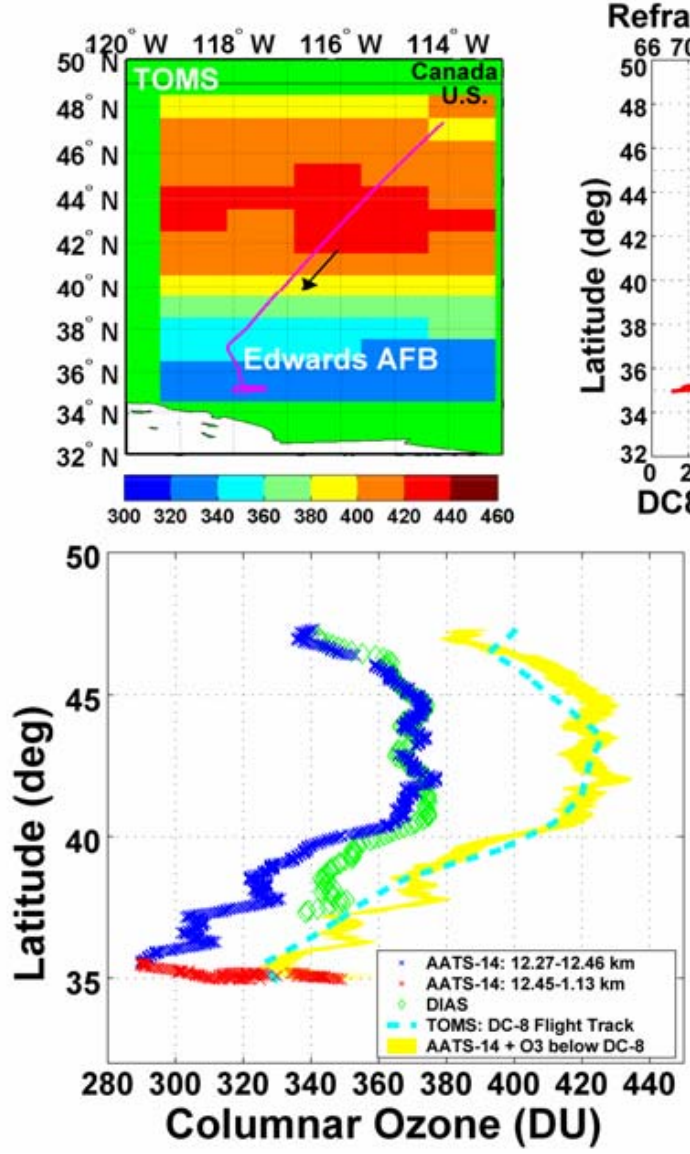
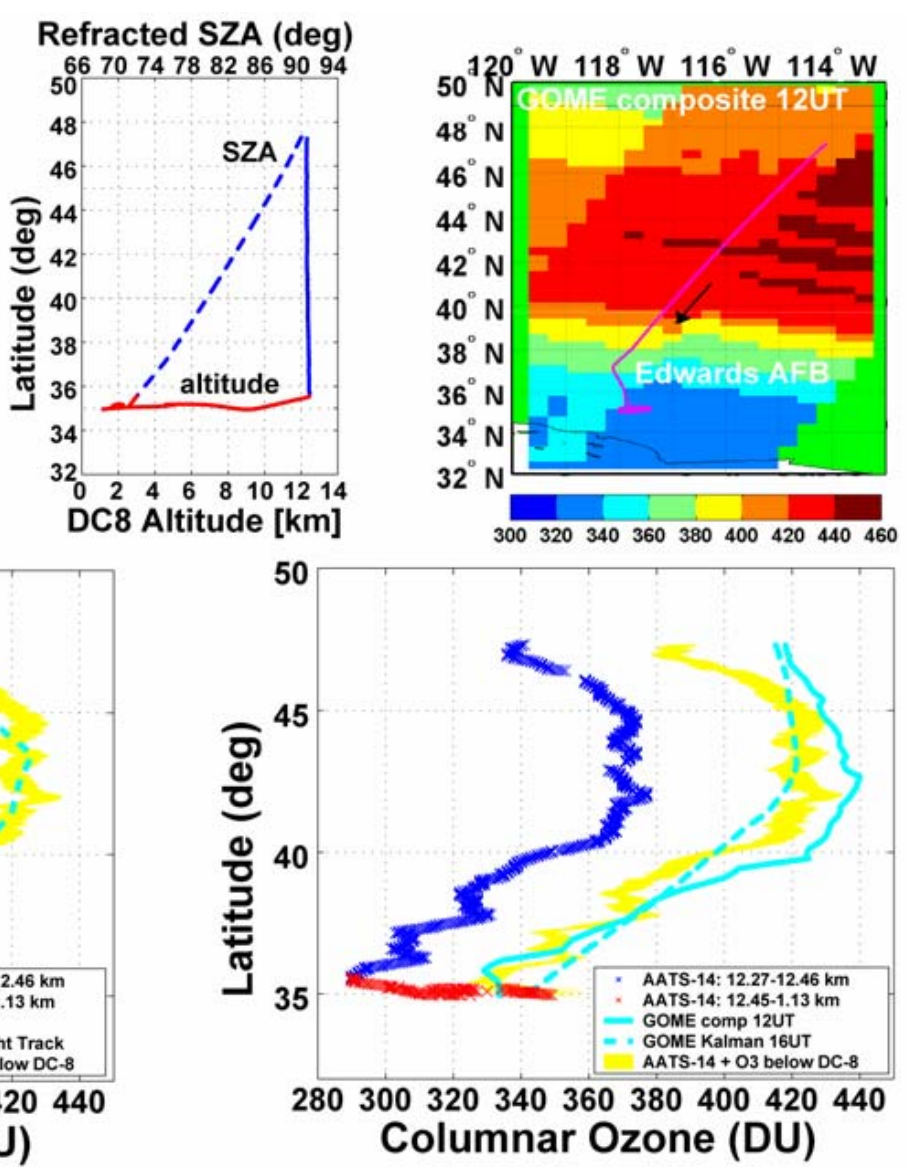

Fig. 10. Comparison of AATS and DIAS columnar ozone retrievals for DC-8 flight of 6 February 2003 with corresponding TOMS and GOME retrievals. Yellow band shows AATS ozone retrieval plus an estimated amount below DC-8 altitude.

Table 4. Mean relative differences between satellite (SAGE or POAM) and AATS-14 columnar ozone: (satellite-AATS)/AATS.

\begin{tabular}{|c|c|c|c|c|c|c|c|c|}
\hline \multirow{4}{*}{$\begin{array}{l}\text { DC-8 Altitude: } \\
\text { SAGE-AATS: }\end{array}$} & & & & & \multirow{3}{*}{$\frac{29 \mathrm{Jan}}{10.3 \mathrm{~km}}$} & \multirow{3}{*}{$\begin{array}{c}31 \mathrm{Jan} \\
9.07 \mathrm{~km}\end{array}$} & \multicolumn{2}{|c|}{ All cases } \\
\hline & \multicolumn{2}{|c|}{19 Jan } & \multicolumn{2}{|c|}{24 Jan } & & & Mean & RMS \\
\hline & $9.77 \mathrm{~km}$ & $10.43 \mathrm{~km}$ & $8.74 \mathrm{~km}$ & $9.90 \mathrm{~km}$ & & & & \\
\hline & $10.6 \%$ & $11.6 \%$ & $0.4 \%$ & $2.7 \%$ & $-4.8 \%$ & $-1.9 \%$ & $3.1 \%$ & $7 \%$ \\
\hline & \multicolumn{2}{|l|}{19 Jan } & \multicolumn{3}{|c|}{21 Jan (three occultations) } & & & \\
\hline DC-8 Altitude: & $11.23 \mathrm{~km}$ & & $9.94 \mathrm{~km}$ & $9.97 \mathrm{~km}$ & $11.17 \mathrm{~km}$ & & & \\
\hline POAM-AATS: & $-4.9 \%$ & & $-2.5 \%$ & $-2.1 \%$ & $-0.7 \%$ & & $-2.6 \%$ & $3 \%$ \\
\hline
\end{tabular}

ozone number density above DC-8 altitude yields RMS differences of $19 \mathrm{DU}$ (7\% of the AATS value) for SAGE-AATS and $10 \mathrm{DU}(3 \%)$ for POAM-AATS. The mean difference for the SAGE-AATS comparisons was $3.1 \%$; for the POAMAATS comparisons it was $-2.6 \%$. Line of sight ozone values from coincident measurements obtained by the three DC-8 solar occultation instruments (AATS-14, DIAS, and GAMS) during the SAGE III solar occultation event on 24 January agree to within RMS relative differences of $2.1 \%$ for AATSDIAS and $0.5 \%$ for AATS-GAMS. Table 4 lists mean relative differences between the satellite and AATS retrievals for each satellite solar occultation event. SAGE values exceeded AATS retrievals for measurements obtained on 19 and 24 January, but were less than the AATS retrievals for 29 and 31 January. POAM retrievals were less than the corresponding AATS values for each comparison. Mean satellite-AATS 

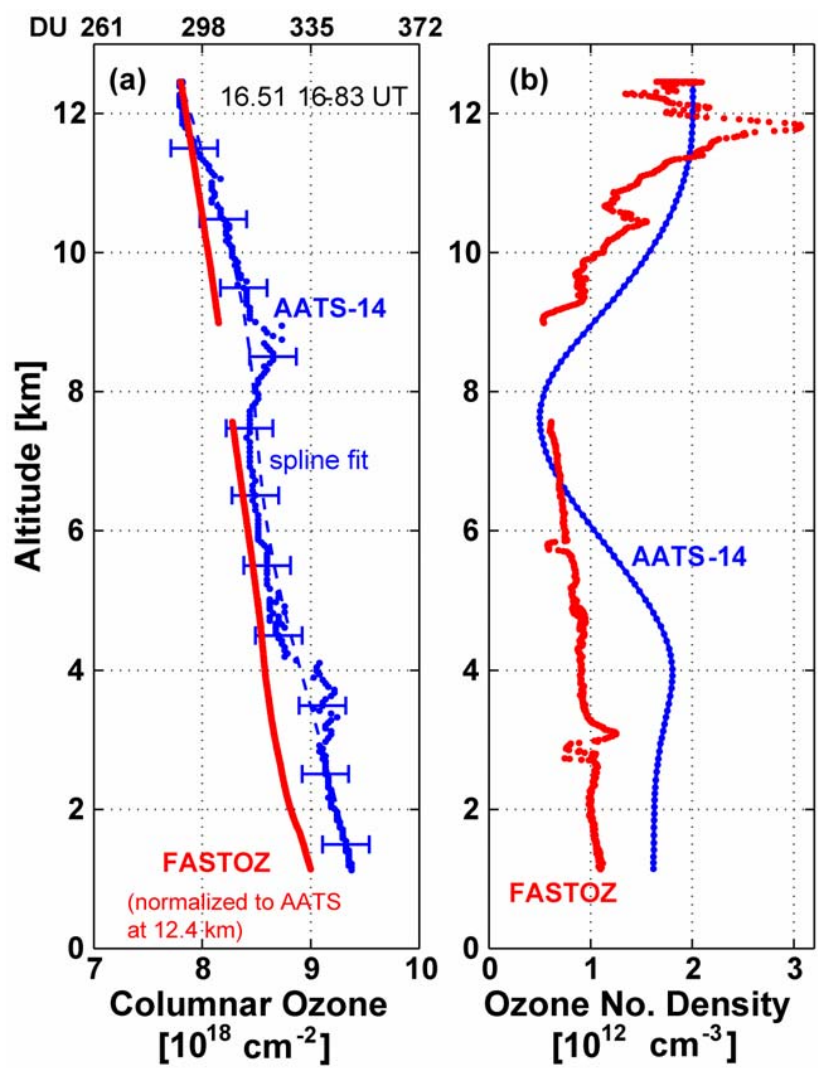

Fig. 11. Comparison of AATS-14 and FASTOZ ozone measurements during DC-8 descent into Edwards AFB on 6 February 2003. FASTOZ measurements of ozone concentration (b) have been normalized to the AATS-14 columnar ozone retrieval at $12.4 \mathrm{~km}$ altitude and vertically integrated for comparison to AATS-14 retrievals in (a). Differentiation of a cubic spline fit to AATS-14 columnar ozone retrievals (a) yields ozone concentrations that are compared to FASTOZ ozone number density in (b).

differences were $<5 \%$ of the AATS value for three of the four SAGE events (six aircraft altitudes), and for the four POAM events. The SAGE-AATS comparisons for the 19 January SAGE solar occultation exhibited the largest mean relative differences with values of $\sim 11 \%$.

To put these findings in the context of other work, we examine recent POAM-SAGE and POAM-SAGE-ozonesonde comparisons, since this is the first SAGE- or POAM-airborne sunphotometer ozone study. We reiterate (cf. Sect. 4.1) that there were no near-coincident measurements by all three of SAGE, POAM, and AATS during SOLVE II. In a prior study, however, Randall et al. (2003) report that POAM III ozone profiles agreed within $\pm 5 \%$ with correlative HALOE, SAGE II, and ozonesonde measurements from 13 to $60 \mathrm{~km}$, with a small POAM bias of up to $\sim 0.1 \mathrm{ppmv}$ from 10 to $12 \mathrm{~km}$. In a comparison of POAM III, HALOE, and SAGE III ozone retrievals obtained between 15 and $40 \mathrm{~km}$ during the 2002 Austral winter, Randall et al. (2005) report differences within $\pm 10 \%$, and often within $\pm 5 \%$. Taha et al. (2004) report similar results for comparison of SAGE III, SAGE II, HALOE, and POAM III ozone retrievals from northern hemisphere measurements. The magnitudes of the RMS and mean relative differences for the SAGE-AATS and POAM-AATS comparisons during SOLVE II are similar to the results of these previous studies, which include many more cases. It is probably unrealistic to expect agreement to better than a few percent in comparisons of satellite-satellite or satelliteairborne sensor measurements, because of uncertainties resulting solely from atmospheric spatial and/or temporal variability.

AATS-14 columnar ozone retrievals from data acquired during extended horizontal transects during three flights (1920 December, 21 January, 6 February) have been compared with corresponding TOMS and GOME total column ozone retrievals. In these comparisons, the AATS values were increased by the estimated amount of ozone below the DC8 altitude, obtained either from a climatological model or from measurements acquired with the on-board fast response chemiluminescent ozone sensor (FASTOZ) during the aircraft ascent at the start of each science flight or descent at the end of each science flight. Resultant AATS and satellite retrievals are found to be mutually consistent for the 21 January and 6 February flights, with RMS differences generally $<10-15$ DU. AATS and DIAS retrievals agree to within an RMS difference of $1 \%$ of the AATS value for the $21 \mathrm{Jan}$ uary flight and $2.3 \%$ for the 6 February flight. Corresponding AATS-GAMS RMS differences are $1.5 \%$ for the 21 January flight, but GAMS data are not available for the 6 February flight. For the round trip DC-8 latitudinal transect from $34^{\circ} \mathrm{N}$ to $22^{\circ} \mathrm{N}$ on $19-20$ December, coincident DC-8 based measurements by AATS-14 and by DIAS yield ozone retrievals that agree with each other to $\sim 1 \%$. After addition of an estimated amount of ozone below the aircraft to the AATS-14 retrievals, the resultant total column ozone values yield a latitudinal gradient that is similar in shape to that observed by TOMS and GOME, but they exceed the satellite values by up to $30 \mathrm{DU}$ at certain latitudes. These differences in absolute magnitude are attributed to spatial and temporal variability that was associated with the dynamics near the subtropical jet but was unresolved by the satellite sensors.

AATS-14 ozone retrievals have been compared directly with high time resolution in-situ ozone measurements (the NASA Langley FASTOZ instrument) during the DC-8 descent into Edwards AFB on 6 February. This was the only opportunity during SOLVE II to conduct this type of indepth comparison of measurements obtained by the two instruments. Corresponding layer ozone values agree to within $\sim 12$ DU for the layer between 12.4 and $1.1 \mathrm{~km}$ altitude. Differentiation of a spline fit to the AATS-14 columnar ozone values yields a coarse vertical profile of ozone number density that is unable to reproduce the fine structure seen by FASTOZ. 
In this study, we have investigated the retrieval of ozone column content from application of the King and Byrne (1976) least squares methodology to airborne sunphotometer retrievals of aerosol optical depth spectra. In general, we found agreement between AATS-14 and near-coincident satellite-derived values of columnar ozone of 3-7\% (RMS and mean differences). These results are similar to values cited in recent studies of POAM and SAGE ozone concentration measurements. Comparison of AATS with DIAS or GAMS retrievals yields RMS differences of less than 0.5$2.3 \%$. Although these small RMS differences do not provide a direct measure of the absolute accuracy of our results, they do confirm the mutual consistency of the simultaneous measurements obtained by the three DC- 8 solar occultation instruments. While we cannot claim that our method of retrieving columnar ozone can provide the $2 \%$ validation accuracy desired by the OMI instrument (Earth Observing System (EOS) Aura Science Data Validation Needs, 2004), we believe that the excellent agreement among the simultaneous measurements obtained by the three solar occultation instruments on board the DC- 8 gives credence to the usefulness of such measurements for satellite validation. We note that the present study differs from the typical satellite sensor validation study in which a ground-based or airborne sensor is combined with a proven analysis technique to assess the accuracy of the satellite sensor measurement. In that sense, the current investigation represents as much an assessment of the feasibility of airborne sunphotometry to retrieve columnar ozone for future validation of satellite-retrieved ozone as it does an assessment of the satellite measurements used in this study. However, we also stress that, prior to the DC8 measurements, the accuracy of the AATS ozone retrievals was extensively tested and characterized (e.g., as a function of airmass) by comparisons to Dobson and Brewer spectrophotometer measurements at Mauna Loa Observatory (cf. Fig. 4).

We conclude that retrieval of ozone column content from multiwavelength airborne sunphotometer measurements in the Chappuis absorption band can provide substantive information for validation of temporally and spatially coincident or near-coincident satellite sensor ozone measurements to a few percent if and only if retrieval uncertainties are minimized by acquiring data under all of the following conditions:

1. The spectral aerosol optical depth near the center of the Chappuis ozone absorption band is less than or equal to the corresponding overlying ozone optical depth, which, for an ozone overburden of $0.3 \mathrm{~atm}-\mathrm{cm}$ (300 DU), corresponds to $0.014,0.041$, and 0.012 for the AATS-14 channels centered at $519.4,604.4$, and $675.1 \mathrm{~nm}$, respectively.

2. Refracted SZAs are $>\sim 80^{\circ}$, corresponding to aerosol and ozone airmass factors $>\sim 5.8$.
3. If results are desired in the form of vertical column contents (rather than slant path column contents or transmissions), the relative shapes of the overlying vertical distributions of aerosol extinction, ozone number density, and neutral molecular number density are known or can be modeled to accuracies yielding airmass factors accurate to a few percent.

4. For SZAs $>\sim 83^{\circ}$, the vertical temperature distribution is sufficiently well known or modeled to permit accurate calculation of atmospheric refraction along the instrument to Sun line of sight.

5. The line of sight is cloud-free.

The AATS-14 measurements used in the SAGE III and POAM III comparisons satisfied all of the above criteria, as did the AATS data acquired during the 21 January horizontal transect and subsequently compared with GOME and TOMS data. Based on the criteria listed above, portions of the 19 December and 6 February flights were not ideal for retrieval of ozone because they included measurements acquired at SZAs as low as $64^{\circ}$ and $70^{\circ}$, respectively. In addition, the 6 February flight also included data taken at lower flight altitudes (during the descent into Edwards AFB) where the AOD represented a larger fraction of the total AOD-plus-ozone optical depth than occurred at flight altitudes above $8.5 \mathrm{~km}$ where most of the SOLVE II AATS-14 data were acquired. Nevertheless, for the time periods during these flights when DIAS measurements were available $\left(\mathrm{SZA}>72^{\circ}\right.$ and altitude $>12 \mathrm{~km}$ on 19 December; $\mathrm{SZA}>74^{\circ}$ and altitude $>12 \mathrm{~km}$ on 6 February), AATS and DIAS columnar ozone retrievals showed excellent agreement to within a few DU.

Acknowledgements. This research has been supported by NASA's Upper Atmosphere Research Program and by funding for its Solar Occultation Satellite Science Team.

Edited by: K. Carslaw

\section{References}

Avery, M. A., Westberg, D. J., Fuelberg, H. E., Newell, R. E., Anderson, B. E., Vay, S. A., Sachse, G. W., and Blake, D. R.: Chemical transport across the ITCZ in the central Pacific during an El Niño-Southern Oscillation cold phase event in March-April 1999, J. Geophys. Res., 106 (D23), 32 539-32 554, doi:10.1029/2001JD000728, 2001.

Box, G. P., Box, M. A., and Krucker, J.: Information content and wavelength selection for multispectral radiometers, J. Geophys. Res., 101, 19211-19214, 1996.

Bittner, M., Dech, S., and Meisner, R.: Monitoring of polar ozone depletion using ERS-2 GOME, Earth Observation Quarterly, 55, 6-10, 1997.

Browell, E. V., Ismail, S., and Grant, W. B.: Differential Absorption Lidar (DIAL) measurements from air and space, Appl. Phys. B, 67, 399-410, 1998. 
Bucholtz, A.: Rayleigh-scattering calculations for the terrestrial atmosphere, Appl. Opt., 34, 2765-2773, 1995.

Clough, S. A. and Iacona, M. J.: Line-by-line calculations of atmospheric fluxes and cooling rates II: Application to carbon dioxide, ozone, methane, nitrous oxide, and the halocarbons, J. Geophys. Res., 100, 16 519-16 535, 1995.

DeMajistre, R. and Yee, J.-H.: Atmospheric remote sensing using a combined extinctive and refractive stellar occultation technique: 2. Inversion method for extinction measurements, J. Geophys. Res., 107(D15), 6-1-6-18, doi:10.1029/2001JD000795, 2002.

Earth Observing System (EOS) Aura Science Validation Needs: Update, Version 1.0, http://deluge.ssec.wisc.edu $\sim \sim$ shis/ AVE_Houston2004/Aura_validation_needs_update_v1_0.pdf, March 2004.

Flittner, D. E., Herman, B. M., Thome, K. J., and Simpson, J. M.: Total ozone and aerosol optical depth inferred from radiometric measurements in the Chappuis absorption band, J. Atmos. Sci., 50, 1130-1121, 1993.

Grant, W. B., Fenn, M. A., Browell, E. V., McGee, T. J., Singh, U. N., Gross, M. R., McDermid, I. S., Froidevaux, L., and Wang, P.-H.: Correlative stratospheric ozone measurements with the airborne UV DIAL system during TOTE/VOTE, Geophys. Res. Lett., 25, 623-626, 1998.

Harder, J. W., Brault, J. W., Johnston, P. V., and Mount, G. H.: Temperature dependent $\mathrm{NO}_{2}$ cross sections at high spectral resolution, J. Geophys. Res., 102, 3861-3879, 1997.

Harrison, L., Michalsky, J., and Berndt, J.: Automated multifilter rotating shadowband radiometer: an instrument for optical depth and radiation measurements, J. Atmos. Sci., 33, 22422251, 1976.

King, M. D. and Byrne, D. M.: A method for inferring total ozone content from the spectral variation of total optical depth obtained with a solar radiometer, J. Atmos. Sci., 33, 2242-2251, 1976.

King, M. D., Byrne, D. M., Reagan, J. A., and Herman, B. M.: Spectral variation of optical depth at Tucson, Arizona between August 1975 and December 1977, J. Appl. Meteor., 19, 723-732, 1980.

Kneizys, F. X., Abreu, L. W., Anderson, G. P., Chetwynd, J. H., Shettle, E. P., Berk, A., Bernstein, L. S., Robertson, D. C., Acharaya, P., Rothmann, L. S., Selby, J. E. A., Gallery, W. O., and Clough, S. A.: The MODTRAN 2/3 Report and LOWTRAN 7 Model, 11 Jan. 1996, Phillips Laboratory, Geophysics Directorate PL/GPOS, 29 Randolph Road, Hanscom AFB, MA 017313010, 1996.

McPeters, R., Logan, J. A., and Labow, G. J.: Ozone climatological profiles for Version 8 TOMS and SBUV Retrievals, EOS Trans. AGU, 84(46), Fall Meet. Suppl., Abstract A21D-0998, 2003.

McPeters, R. D., Bhartia, P. K., Krueger, A. J., Herman, J. R., Wellemeyer, C. G., Seftor, C. J., Jaross, G., Torres, O., Moy, L., Labow, G., Byerly, W., Taylor, S. L., Swissler, T., and Cebula, R. P.: Earth Probe Total Ozone Mapping Spectrometer (TOMS) Data Products User's Guide, NASA/TP-1998-206895, November 1998.

Meisner, R., Bittner, M., and Dech, S.: Computer animation of remote sensing-based time series analysis, IEEE Transactions on Geoscience and Remote Sensing, 37, 1100-1106, 1999.

Michalsky, J. J., Liljegren, J. C., and Harrison, L. C.: A comparison of sun photometer derivations of total column water vapor and ozone to standard measures of same at the Southern Great Plains
Atmospheric Radiation Measurement site, J. Geophys. Res., 100, 25 995-26 003, 1995.

Michalsky, J., Beauharnois, M., Berndt, J., Harrison, L., Kiedron, P., and Min, Q.: $\mathrm{O}_{2}-\mathrm{O}_{2}$ absorption band identification based on optical depth spectra of the visible and near-infrared, Geophys. Res. Lett., 26, 1581-1584, 1999.

NASA Langley Research Center, SAGE III algorithm theoretical basis document: Solar and lunar algorithm, Rep. LaRC 475-00108, Vers. 2.1, Available at: http://eospso.gsfc.nasa.gov, Hampton, VA, 2002.

Randall, C. E., Rusch, D. W., Bevilacqua, R. M., Hoppel, K. W., Lumpe, J. D., Shettle, E., Thompson, E., Deaver, L., Zawodny, J., Kyrö, E., Johnson, B., Kelder, H., Dorokhov, V. M., KönigLanglo, G., and Gil, M.: Validation of POAM III ozone: Comparisons with ozonesonde and satellite data, J. Geophys. Res., 108(D12), 4367, doi:10.1029/2002JD002944, 2003.

Randall, C. E., Manney, G. L., Allen, D. R., Bevilacqua, R. M., Hornstein, J., Trepte, C., Lahoz, W., Ajtic, J., and Bodeker, G.: Reconstruction and simulation of stratospheric ozone distributions during the 2002 Austral winter, J. Atmos. Sci., 62, 748764, 2005.

Reagan, J., Thome, K., Herman, B., Stone, R., Deluisi, J., and Snider, V.: A comparison of columnar water-vapor retrievals obtained with near-IR solar radiometer and microwave radiometer measurements, J. Appl. Meteorol., 34, 1384-1391, 1995.

Rothman, L. S., Barbe, A., Benner, D. Chris, Brown, L. R., CamyPeyret, C., Carleer, M. R., Chance, K., Clerbaux, C., Dana, V., Devi, V. M., Fayt, A., Flaud, J.-M., Gamache, R. R., Goldman, A., Jacquemart, D., Jucks, K. W., Lafferty, W. J., Mandin, J.-Y., Massie, S. T., Nemtchinov, V., Newnham, D. A., Perrin, A., Rinsland, C. P., Schroeder, J., Smith, K. M., Smith, M. A. H., Tang, K., Toth, R. A., Vander Auwera, J., Varanasi, P., and Yoshino, K.: The HITRAN molecular spectroscopic database: edition of 2000 including updates through 2001, J. Quant. Spectr. Rad. Transfer., 82, 5-44, 2003.

Russell, P. B., Livingston, J. M., Dutton, E. G., Pueschel, R. F., Reagan, J. A., DeFoor, T. E., Box, M. A., Allen, D., Pilewskie, P., Herman, B. M., Kinne, S. A., and Hofmann, D. J.: Pinatubo and pre-Pinatubo optical-depth spectra: Mauna Loa measurements, comparisons, inferred particle size distributions, radiative effects, and relationship to lidar data, J. Geophys. Res., 98, 22 969-22 985, 1993a.

Russell, P. B., Livingston, J. M., Pueschel, R. F., Reagan, J. A., Browell, E. V., Toon, G. C., Newman, P. A., Schoeberl, M. R., Lait, L. R., Pfister, L., Gao, Q., and Herman, B. M.: PostPinatubo optical depth spectra vs. latitude and vortex structure: Airborne tracking sunphotometer measurements in AASE II, Geophys. Res. Lett., 20, 2571-2574, 1993b.

Russell, P. B., Livingston, J. M., Schmid, B., Eilers, J., Kolyer, R., Redemann, J., Ramirez, S., Yee, J-H., Swartz, W., Shetter, R., Trepte, C., Thomason, L., Risley, Jr., A., Wenny, B., Zawodny, J., Chu, W., Pitts, M., Lumpe, J., Randall, C., and Bevilacqua, R.: Aerosol optical depth measurements by airborne sun photometer in SOLVE II: Comparison to SAGE III, POAM III and airborne spectrometer measurements, Atmos. Chem. Phys., 5, 1311-1339, 2005,

SRef-ID: 1680-7324/acp/2005-5-1311. 
Schmid, B., and Wehrli, C.: Comparison of sun photometer calibration by Langley technique and standard lamp, Appl. Opt., 34, 4500-4512, 1995.

Schmid, B., Thome, K. J., Demoulin, P., Peter, R., Matzler, C., and Sekler, J.: Comparison of modeled and empirical approaches for retrieving columnar water vapor from solar transmittance measurements in the 0.94-mm region, J. Geophys. Res., 101, 93459358, 1996.

Schmid, B., Michalsky, J. J., Slater, D. W., Barnard, J. C., Hathore, R. N., Liljegren, J. C., Holben, B. N., Eck, T. F., Livingston, J. M., Russell, P. B., Ingold, T., and Slutsker, I.: Comparison of columnar water-vapor measurements from solar transmittance methods, Appl. Opt., 40, 1886-1896, 2001.

Schmid, B., Redemann, J., Russell, P. B., Hobbs, P. V., Hlavka, D. L., McGill, M. J., Holben, B. N., Welton, E. J., Campbell, J. R., Torres, O., Kahn, R. A., Diner, D. J., Helmlinger, M. C., Chu, D. A., Robles-Gonzalez, C., and De Leeuw, G.: Coordinated airborne, spaceborne, and ground-based measurements of massive, thick aerosol layers during the dry season in Southern Africa, J. Geophys. Res., 108(D13), 8496, doi:10.1029/2002JD002297, 2003.

Shetter, R. E. and Muller, M.: Photolysis frequency measurements using actinic flux spectroradiometry during the PEM-Tropics mission: Instrumentation description and some results, J. Geophys. Res., 104, 5647-5661, 1999.

Swartz, W. H., Yee, J.-H., Shetter, R. E., Hall, S. R., Lefer, B. L., Livingston, J. M., Russell, P. B., Browell, E. V., and Avery, M. A.: Column ozone and aerosol optical properties retrieved from direct solar irradiance measurements during SOLVE II, Atmos. Chem. Phys., 5, 611-612, 2005,

SRef-ID: 1680-7324/acp/2005-5-611.
Thomason, L. W., Herman, B. M., and Reagan, J. A.: The effect of atmospheric attenuators with structured vertical distributions on air mass determinations and Langley plot analyses, J. Atmos. Sci., 40, 1851-1854, 1983.

Taha, G. and Box, G. P.: New method for inferring total ozone and aerosol optical thickness from multispectral extinction measurements using eigenvalue analysis, Geophys. Res. Lett., 26, 30853088, 1999.

Taha, G., Thomason, L. W., Trepte, C. R., and Chu, W. P.: Validation of SAGE III data products Version 3.0, Quadrennial Ozone Symposium, Kos, Greece, May-June 2004.

Vervack Jr., R. J., Yee, J.-H., Carbary, J. F., and Morgan, F.: Atmospheric remote sensing using a combined extinctive and refractive stellar occultation technique: 3 . Inversion method for refraction measurements, J. Geophys. Res., 107(D15), 7-1-7-19, doi:10.1029/2001JD000796, 2002.

Yee, J.-H., Vervack Jr., R. J., DeMajistre, R., Morgan, F., Carbary, J. F., Romick, G. J., Morrison, D., Lloyd, S. A., DeCola, P. L., Paxton, L. J., Anderson, D. E., Krishna Kumar, C., and Meng, CI.: Atmospheric remote sensing using a combined extinctive and refractive stellar occultation technique: 1 . Overview and proofof-concept observations, J. Geophys. Res., 107(D14), 15-1-1513, doi:10.1029/2001JD000794, 2002. 